\title{
İran'da Doğrudan Yabancı Sermaye Yatırımları: Ekonomik Müşevvikler ve Kurumsal Kısıtlar
}

\author{
Emre Saygin*
}

\section{Öz}

$\mathrm{Bu}$ çalışmada; ideoloji-baskın, sosyal tansiyonu yüksek ve rant-odaklı bir ekonomi örneği olarak İran'da, ekonomik çeşitliliğin sağlanmasına ve öncelikli sektörlerin büyümesine olumlu katkı sağlaması beklenen doğrudan yabancı sermaye yatırımlarını cezbetmesi muhtemel faktörlerin mevcut durumunun tespit edilmesi hedeflenmiştir. Bu bağlamda, Devrim'den günümüze İran'da makroekonomik göstergelerin gelişimi, yerel unsurların ekonomik yapıya etkileri, kurumsal kalite düzeyi ve yatırım ikliminin görünümü ele alınmıştır. Sonuç olarak, büyük nüfusu, gelişime açık piyasa yapısı, stratejik coğrafi konumu, doğal kaynak zenginliği gibi ekonomik müşevviklere rağmen İran'ın, dışlayıcı politik ve sosyal kurumları nedeniyle potansiyelinin oldukça altında doğrudan yabancı sermaye akımına ev sahipliği yapmak durumunda kaldığg anlaşılmıştır.

Anahtar Kelimeler: İran, Doğrudan Yabancı Sermaye Yatırımları, Kurumlar, Yatırım İklimi.

Dr. Bağımsız Akademisyen, Kamu İç Denetçisi, sayginemre@gmail.com, 05327874416. 


\title{
Foreign Direct Investments in İran: Economic Incentives and Institutional Barriers
}

\author{
Emre Saygin*
}

\begin{abstract}
In this study, it was aimed to determine the current situation of the factors that are likely to attract FDI, which is expected to provide economic diversity and contribute positively to the growth of the priority sectors in Iran as an example of ideology-raid, social tension and rant-focussed economy. In this context, the development of macroeconomic indicators, the effects of local factors on the economic structure, the institutional quality level and the appearance of the investment climate are discussed from the Revolution to nowadays in Iran. As a result, it has been understood that despite the economic incentives such as large population, developing open market structure, strategic geographical location and natural resource richness; Iran has to host a foreign direct investment flows well below its potential due to the exclusionary political and social institutions of Iran.
\end{abstract}

Keywords: Iran, Foreign Direct Investment, Institutions, Investment Climate

Dr. sayginemre@gmail.com, 05327874416. 


\section{Giriş}

İran; her yönüyle küresel politikanın odağını teşkil eden Ortadoğu ve Kuzey Afrika (ODKA) bölgesinin stratejik ehemmiyeti haiz bir noktasında yer alan, gerek tarihi geçmişi ve devlet geleneği gerekse İslam Dünyas1 içerisindeki farklılaşan mezhep yapısı itibarıyla nevi şahsına münhasır özellikler barındıran, nicelik ve niteliği bakımından bölgenin en büyük ve en dinamik nüfus yapısına sahip ekonomilerden birisi olan, sinırları dâhilinde petrol ve doğalgaz gibi kritik önemdeki enerji kaynaklarına bol miktarda sahip bulunan bir ülkedir.

Bununla birlikte İran, 1979 yılında gerçekleşen "İslam" Devrimi ile birlikte iradi ve/veya gayrı iradi şekilde sürdürüle gelen ve zaman zaman sertleşecek ya da yumuşayacak şekilde tonu farklılaşan kapalı bir sosyoekonomik yapıya, bu bağlamda uzun yıllara dayanan ve enerji-odaklı üretim ilişkilerinin gölgesinde gelişen devlet-toplum-piyasa ilişkileri nedeniyle zayıf temeller ve bozuk dengeler üzerine kurulu istikrarsız bir ekonomik sisteme ve nihayet hem mezhepsel yayılmacılık politikasının devamlılığını sağlamak hem de konjonktürel olarak farklılaşan dış siyasi ilişkilerin motive edici etkisine binaen, yani güvenlik kaygısıyla nispigelişmiş teknolojik kapasiteye sahip bir ülke görünümü arz etmektedir.

Bu noktada İran'1n, temel hak ve özgürlüklerin güvence düzeyi, siyasal istikrar ve sürdürülebilirlik/öngörülebilirlik seviyesi, maddi ve entelektüel/fikri mülkiyet haklarının korun(a)maması endişesi, hukuk düzeninin etki(n)sizliği, yolsuzluk ve kayırmacılık algısı, gerek fiziki altyapı gerekse yatırım ikliminin cazip olmaması gibi dışlayıcı ve sınırlayıcı faktörler nedeniyle, sahip olduğu iktisadi potansiyeli sosyal refaha tahvil etmek hususunda başarılı olamadığını söylemek yanlış olmayacaktır. Keza, yakın vadede gerçekleşen neredeyse bütün seçim dönemlerinde yükselen toplumsal tansiyonun, her ne kadar dış destekli provokasyonlardan kaynaklandığı ifade edilse de, 2017 yılının son günlerinde Arap İsyanları sürecini andıracak şekilde yoğun bir gösteriler silsilesine dönüşmesi de, bu savı desteklemektedir.

Kuşkusuz konunun politik, sosyal, ekonomik ve sair her veçhesi kendi özelinde detaylı tetkikleri gerektirmektedir. Ancak bizim bu çalışmadaki hedefimiz, İran'ın ekonomik kalkınma problemine, küreselleşme süreci ile birlikte özellikle gelişmekte olan ülkeler açısından dış finansman kaynağ1 ve teknoloji ve yönetim bilgisi transferi aracı olarak değerlendiri- 
len doğrudan yabancı sermaye yatırımları ekseninde farklı bir pencereden bakmaktır. Öyle ki doğrudan yabancı sermaye yatırımlarının diyalektiğ gerek ev sahibi ülke gerekse çok uluslu işletmeler (ÇUi) açısından kazankazan prensibine dayanmakta olup; bir taraftan kaynak ihtiyac1 olan ülkeler yabancı yatırımcıların kararlarını çelmek maksadıyla siyasal, sosyal ve politik ku-rumlarını iyileştirmekte, öte yandan ise uygun yatırım ikliminin sağladığı avantajlardan yararlanan dış yatırımcılar hammadde temini, etkin üretim, pazar avantajı ve benzeri birçok fayda sağlama imkânı bulmaktadırlar.

Bu kapsamda öncelikle konunun kavramsal çerçevesine kısaca değinilmesi, sonrasında İran'ın küresel doğrudan yabancı sermaye akımlarından aldığı payın tespit edilmesi, bilahare İran'ın yabancı yatırımcıları çekmeye yönelik ekonomik müşevviklerinin ve kurumsal yapısı ile yatırım ikliminin, Dünya Bankası'nın Dünya Kalkınma Göstergeleri veritabanı, Birleşmiş Milletler Ticaret ve Kalkınma Konferansı (UNCAD)'nın Dünya Yatırım Raporu, diğer birçok uluslararası ekonomik kuruluş ya da sivil toplum örgütünün çeşitli metotlar dâhilinde ve genelde yıllık olarak üreterek yönetişim, özgürlük, kurumsal kalite ve benzeri adlarla yayımladıkları raporlar ve hiç şüphesiz İran'da hukuki düzenin belirleyici unsuru olan anayasa metni ve doğrudan yabancı sermaye yatırımlarına yönelik ikili ve çok taraflı uluslararası anlaşmalardan yararlanılmak suretiyle tespit ve analiz edilmesi, nihayet uygun bir yatırım ikliminin geliştirilebilmesine yönelik bazı kritik odak noktalar belirlenerek bunlara ilişkin bazı politika önerileri sunulması planlanmaktadır.

\section{Doğrudan Yabancı Sermaye Yatırımları (DYSY): Kavramsal Çerçeve}

Uluslararası literatürde Foreign Direct Investment - FDI şeklinde kullanılan ve Türkçe yazına Doğrudan Yabancı Sermaye Yatırımı - DYSY olarak aktarılan kavram, esasen iktisat ve finans literatürüne ait farklı terimlerin bir arada kullanıldığg ve anlam itibarıly birbiri içine geçmiş bulunan yeni bir terkibi ifade etmektedir.

Günlük yaşamda menkul ya da gayrimenkul alımı, kıymetli evrak veya madenlerin gelir getirici işlerde değerlendirilmesi gibi transfer nitelikli işlemler için kullanılan yatırım kavramı, iktisadi manasıyla, insanların, gelirlerinin tüketmeyerek tasarruf ettikleri kısmıyla toplam maddi üretim 
araçları miktarına yaptıkları katkı olarak tanımlanmaktadır. ${ }^{1}$ Diğer taraftan, bir girişimin gerçekleştirilebilmesini sağlayacak parayı veya bir ürünün üretim maliyetini anlatmak için kullanılan sermaye kavramı ise ekonomi literatüründe bizzat üretim araçlarının kendisini işaret etmektedir. ${ }^{2}$

Bu bağlamda; bir ülkenin karşılıksız olarak dış ülkelerde yerleşik kişilerden temin ettiği iktisadi kaynaklara yabancı sermaye yatırımı ismi verilirken; ${ }^{3}$ küreselleşme sürecinin en önemli aktörü olarak öne çıkan çok uluslu işletmelerin ve diğer şirketlerin, ana merkezlerinin bulunduğu kaynak ülke dışındaki bir ev sahibi ülkede üretim ve diğer ekonomik aktivitelerde bulunmak maksadıyla tesis kurma ve/veya satın alma, şube açma ve sair yöntemlerle varlık edinmelerine ise doğrudan yabancı sermaye yatırl$m \imath$ denilmektedir. ${ }^{4}$

Çok uluslu işletmelerin doğrudan yabancı sermaye yatırımı motivasyonlarına ilişkin teorik çerçeve, kaynakların rasyonel kullanımını esas alan klasik iktisadî savlardan, makro ve mikro ölçekli avantaj sağlamaya yönelik farklı tezlere kadar birçok farklı şekillerde çizilmiş ise de günümüzde en çok referans verilen açıklamayı Dunning'in Eklektik Paradigma olarak da adlandırılan OLI Yaklaşımı oluşturmaktadır. Buna göre çok uluslu işletmelerin, doğrudan yabancı sermaye yatırımı gerçekleştirerek kâr elde edebilmeleri için mülkiyet, konum ve öğrenme avantajlarının bir arada olması gerekmektedir. Diğer taraftan, yine Dunning tarafından tasnif edildiği şekliyle; çok uluslu işletmeler, doğrudan yabancı sermaye yatırımına yönelirken pazar arama, kaynak arama, etkinlik arama ve stratejik aktif arama gibi unsurları özellikle göz önünde bulundurmaktadırlar. ${ }^{5}$

Buna göre, Tablo 1'de derlediğimiz üzere, doğrudan yabancı sermaye yatırımlarının belirleyici unsurları temel olarak beş başlık altında tasnif edil-

P. A. Samuelson (1973), İktisat, Çev: D. Demirgil, Gözden Geçirilmiş İlaveli Yeni Bası, İstanbul: Menteş Kitabevi, s.213-4 ve s.235.

2 Samuelson, A.e., s.51.

3 K. Bulutoğlu (1970), 100 Soruda Türkiye'de Yabancı Sermaye, İstanbul: Gerçek Yayınevi, s.5.

4 H. Seyidoğlu (2001a), Uluslararası Finans, 3. Bask1, İstanbul: Güzem Yayınları, s.397.

J. H. Dunning (1992), Multinational Enterprises and the Global Economy, MA: Addison-Wesley; S. D. Cohen (2007), Multinational Corporations and Foreign Direct Investment: Avoiding, Simplicity, Embracing Complexity. New York: Oxford University Press, s.125-6. 
mektedir: i) Çok uluslu işletmelerin stratejik-davranışsal öncelikleri, ii) Makroekonomik performans ve pazar büyüklüğü iii) Yerel/değişken faktörler ve coğrafi konum, iv) Kapsayıcı kurumsal yapı, v) Avantajlı yatırım ortamı. İlk üç faktör çok uluslu işletmeler açısından çekici nitelik taşımakta olup doğrudan yabancı sermaye yatırımlarının arz yönünü oluşturmakta, son iki faktör ise dış finansal kaynak ihtiyacı bulunan ülkelerin bizzat doğrudan yabancı sermaye yatırımlarını cezbetmeye matuf talep yönünü ifade etmektedir.

Çok uluslu işletmelerin stratejik-davranışsal öncelikleri, esasen kendi piyasa değerlerini ve kurumsallaşma seviyelerini arttırmaya yönelik motivasyonlarını ifade etmektedir. Bu faktörler; çok uluslu işletmelerin ticari sırlarını paylaşamadığı ve/veya kendi markasını kullanmasının gerektiği durumlarda, ev sahibi ülkede kurulmuş bulunan yerel şirketlerin marka avantajını kullanmanın gerekli olduğu hallerde, parası reel olarak değer kaybına uğrayan ülkelerde maliyet avantajı ortaya çıkardığ 1 üretim esnekliğinden faydalanmak maksadıyla, üretim faaliyetlerini küresel düzeyde çeşitlendirerek kaynak ülkedeki risklerden kaçınmak amacıyla ve bazen ise üretim faaliyetinin farklı mekânlara yayıldığg durumlarda yönetim işlevini tek elde toplayarak etkinleştirebilmek nedeniyle ortaya çıkmaktadır. ${ }^{6}$

$\mathrm{Bu}$ faktörlerle bağlantılı olarak, ev sahibi ülkenin harcanabilir milli gelir düzeyi, ortalama tüketim eğilimi, kentleşme oranı ve nüfusun yaş gruplarına göre dağılımıyla bağlantılı olarak değişebilen tüketim kalıpları, sahip olduğu doğal kaynakların niceliği ve niteliği, işgücünün eğitim ve yeni üretim teknolojilerine adaptasyon seviyesi, komşu ülkelerle ve yakın coğrafyasıyla ikili ilişkilerinin düzeyi ve sıhhati ile potansiyel ihraç pazarlarına yakınlığı da, çok uluslu işletmeler açısından cezbedici unsurlardır.

Çok uluslu işletmelerin DYSY'ne ilişkin motivasyonlarını arttıran önemli unsurların diğer kısmını da, ev sahibi ülkenin kurumsal yapısının kalite düzeyi ve yatırımcıları çekmeye yönelik oluşturduğu yatırım iklimi oluşturmaktadır. Genel olarak temel hak ve özgürlükler, örgütlenme ve kendini açıklama hürriyeti, siyasal sistemin devamlılığı ve gayrı meşru müdahalelere karşı korunaklı olma düzeyi, etkin bir adli sistemin ve hukuk güvenliği ortamının oluşturulması suretiyle hem mülkiyet haklarının güvence altında

H. Seyidoğlu (2001b), Uluslararası İktisat-Teori, Politika ve Uygulama, 14. Bask1, İstanbul: Güzem Yayınları, s.666-8. 
olması hem de kişiler ve/veya kurumlar arası sözleşmelerin etkin bir şekilde hayata geçirilebilmesini temin edecek altyapının oluşturulması, yolsuzluğa mahal vermeyecek etkin bir bürokratik yapının teşekkül ettirilmesi ve iş yapma prosedürlerinin basitleştirilmesi ile nihayet uluslararası yatırım hukukuna entegrasyon seviyesi gibi etmenler, ev sahibi ülkelerin çok uluslu işletmeleri çekmeye yönelik gayretlerinin yoğunlaştığı noktaları teşkil etmektedir.

Tablo 1: Doğrudan Yabancı Sermaye Yatırımı Motivasyonları

\begin{tabular}{|c|c|c|c|}
\hline & $\begin{array}{l}\text { Ana } \\
\text { Belirleyici } \\
\text { Faktör }\end{array}$ & Alt Belirleyici Faktör & İlgili Göstergeler \\
\hline \multirow{8}{*}{ 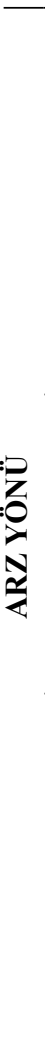 } & $\begin{array}{l}\text { ÇUI'lerin } \\
\text { Stratejik- } \\
\text { Davranışsal } \\
\text { Öncelikleri }\end{array}$ & $\begin{array}{l}\text { Aktarılamayan bilgilerin varlığı- } \\
\text { şirket unvanı ve ticari sırların } \\
\text { korunması. } \\
\text { Ev sahibi ülkede mevcut olan } \\
\text { şirketlerin marka ve unvanından } \\
\text { yararlanmak. } \\
\text { Üretim esnekliğinin sağlanması. } \\
\text { Yatırımlarda uluslararası } \\
\text { cessitlendirme. } \\
\text { Üretim faaliyetlerinin yatay ve dikey } \\
\text { olarak bütünleștirilmesi çabası. }\end{array}$ & $\begin{array}{l}\text { Bu alt-faktörlere ilişkin } \\
\text { göstergeler, ilgili ÇUI'nin } \\
\text { kendisinde mahfuzdur. }\end{array}$ \\
\hline & \multirow{3}{*}{$\begin{array}{l}\text { Makro } \\
\text { Ekonomik } \\
\text { Performans } \\
\text { ve Pazar } \\
\text { Büyüklüğü }\end{array}$} & Ev sahibi ülkenin pazar büyüklüğü. & $\begin{array}{l}\text { Reel ve potansiyel GSYİH, kişi } \\
\text { bașına düșen milli gelir. }\end{array}$ \\
\hline & & $\begin{array}{l}\text { Ev sahibi ülke vatandaşlarının } \\
\text { tüketim eğilimi, tüketim potansiyeli } \\
\text { ve tüketim kalıpları. }\end{array}$ & $\begin{array}{l}\text { Ortalama tüketim eğilimi, } \\
\text { tüketimin mal ve hizmetlere } \\
\text { göre dağ } 1 \text { lımı. }\end{array}$ \\
\hline & & $\begin{array}{l}\text { Ev sahibi ülkenin nüfusu, kentleşme } \\
\text { oranı, kültürel özellikleri. }\end{array}$ & $\begin{array}{l}\text { Nüfus artış hızı,yaş gruplarına } \\
\text { ve kırsal-kentsel yaşam } \\
\text { alanlarına göre dağılımı. }\end{array}$ \\
\hline & \multirow{4}{*}{$\begin{array}{l}\text { Yerel/ } \\
\text { Değișken } \\
\text { Faktörler ve } \\
\text { Coğrafi } \\
\text { Konum }\end{array}$} & $\begin{array}{l}\text { Ev sahibi ülkenin doğal kaynak } \\
\text { sahipliği. }\end{array}$ & $\begin{array}{l}\text { Doğal kaynak ihracatı, doğal } \\
\text { kaynak rant gelirleri. }\end{array}$ \\
\hline & & $\begin{array}{l}\text { Ev sahibi ülkenin kendine özel } \\
\text { (eğitimli işgücü, teknolojik } \\
\text { gelișmișlik vb.) diğer değișkenleri. }\end{array}$ & $\begin{array}{l}\text { Okullaşma oranı, } \\
\text { yükseköğrenime kaydolma } \\
\text { oranı. }\end{array}$ \\
\hline & & $\begin{array}{l}\text { Ev sahibi ülkenin hammadde } \\
\text { kaynaklarına yakınlığı. }\end{array}$ & $\begin{array}{l}\text { Coğrafi konum ve ikili } \\
\text { ilişkilerin durumu. }\end{array}$ \\
\hline & & $\begin{array}{l}\text { Ev sahibi ülkenin potansiyel ihraç } \\
\text { pazarlarına yakınlığı. }\end{array}$ & $\begin{array}{l}\text { Yakın çevredeki ülkelerin nüfus } \\
\text { ve Pazar büyüklükleri. }\end{array}$ \\
\hline
\end{tabular}




\begin{tabular}{|c|c|c|c|}
\hline \multirow{8}{*}{ 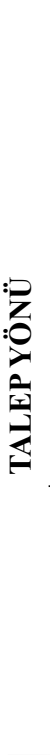 } & \multirow{5}{*}{$\begin{array}{l}\text { Kapsayıcı } \\
\text { Kurumsal } \\
\text { Yapı }\end{array}$} & Ekonomik özgürlük & $\begin{array}{l}\text { Mali, finansal, ticari özgürlük } \\
\text { düzeyi. }\end{array}$ \\
\hline & & Siyasal istikrar/şiddetsizlik & $\begin{array}{l}\text { Demokratikleşme düzeyi, askeri } \\
\text { darbe ve müdahale eğilimi. }\end{array}$ \\
\hline & & Hukukun üstünlüğü & $\begin{array}{l}\text { Mülkiyet hakları güvencesi, } \\
\text { etkin adli sistem, sözleşmelerin } \\
\text { uygulanabilirliği. }\end{array}$ \\
\hline & & Yolsuzluğun kontrolü & $\begin{array}{l}\text { Adam kayırma ve nepotizm } \\
\text { uygulamalarının sıklığ } 1 .\end{array}$ \\
\hline & & Bürokratik etkinlik & $\begin{array}{l}\text { Prosedürlerin muğlaklığı ve } \\
\text { karmaşıklığı ile kırtasiyecilik } \\
\text { alıșkanlığı. }\end{array}$ \\
\hline & \multirow{3}{*}{$\begin{array}{l}\text { Avantajlı } \\
\text { Yatırım } \\
\text { Ortamı }\end{array}$} & Yatırım hukukunun çerçevesi & $\begin{array}{l}\text { Uluslararas1 yatırım hukukuna } \\
\text { entegrasyon durumu. }\end{array}$ \\
\hline & & Girişim özgürlüğü ve basitliği & $\begin{array}{l}\text { İş yapma prosedürlerinin işlem } \\
\text { maliyeti ve etkinliği. }\end{array}$ \\
\hline & & $\begin{array}{l}\text { Yatırım ve Yatırımcıların } \\
\text { Korunmasına Yönelik Mekanizmalar }\end{array}$ & $\begin{array}{l}\text { Yatırım ve yatırımcıların } \\
\text { korunmasına yönelik } \\
\text { düzenlemeler. }\end{array}$ \\
\hline
\end{tabular}

Kaynak: Tarafımızdan derlenmiştir.

Diğer yandan, ister arz ister talep yönlü olsun, çok uluslu işletmelerin doğrudan yabancı sermaye yatırımı metotları da konunun bir diğer önemli noktasını oluşturmaktadır. Şöyle ki çok uluslu işletmeler, doğrudan yabancı sermaye yatırımı gerçekleştirirken bir veya daha çok sayıda yerel şirketle ortak girişim oluşturmak, mülkiyeti tek başına kendisine ait yeni bir bağlı şirket kurmak, mevcut bir yerel firma ile birleşmek veya onu satın almak, bir ya da daha çok ortak ile stratejik birlikler vücuda getirmek gibi farklı stratejiler izleyebilmektedirler. ${ }^{7}$ Bütün bu belirleyici/motive edici etkenler ile birlikte doğrudan yabancı sermaye yatırımlarına dair ev sahibi ülkenin gerek uluslararası düzeyde tabi olduğu iki taraflı yatırım anlaşmaları ve çok taraflı yatırım anlaşmaları, gerekse ulusal ölçekte yürürlüğe koyduğu yabanc1 yatırımlara dair teşvik edici ve yabancı yatırımcılara ilişki koruyucu/gözetici unsurlar barındıran hukuki çerçevenin oldukça önem arz ettiği bilinmektedir. $^{8}$

M. Mucuk (2011), Doğrudan Yabancı Sermaye Yatırımlarl - Teori ve Türkiye Uygulaması, Konya: Çizgi Kitabevi, s.14-21.

8 M. Baykal (2014), Hukuksal ve Kurumsal Bağlamda Amerika Birleşik Devletleri ve Türkiye'de Doğrudan Yabancı Yatırımlar, İstanbul: On İki Levha Yayıncılık, s.33-5. 
Nihayet, kavramsal çerçeve sunulurken, doğrudan yabancı sermaye yat1rımlarının, özellikle de ev sahibi ülke üzerinde ortaya çıkaracağı etkilere de değinmekte fayda vardır. Literatürdeki çalışmaların, çok nadir bir kısmı dışarıda tutulduğunda neredeyse tamamına yakınında, doğrudan yabancı sermaye yatırımlarının ev sahibi ülkenin ekonomik performansı üzerinde, teknoloji kullanımı, üretim metodu, marka ve patent etkisi, yurtiçi tasarrufları arttırma, ödemeler dengesi açığını dengeleme, istihdama katkı sağlama ve sair muhtelif yollarla olumlu bir etki ortaya çıkardığını kanıtlanmaktadir. ${ }^{9}$

Oldukça kapsamlı olan bu literatürde elde edilen bulgular, DYSY'nın olumlu ve olumsuz etkileri olarak Kegley ve Blanton tarafindan kapsamlı bir şekilde derlenmiştir. Buna göre doğrudan yabancı sermaye yatırımlar1, ev sahibi ülkede; ticari faaliyetin önündeki engellerin kaldırılması yönündeki gayretleri ile dış ticaret hacmi artışına katkı sağlamak, yatırım sermayesi oluşumuna destek olarak kalkınmanın önünü açmak, dış borç finansmanında ve geri ödenmesinde destek sağlamak, AR-GE yatırımları suretiyle üretimde teknoloji artışına aracılık etmek, ölçek ekonomilerine katkı sağlayarak üretim maliyetlerinin azalmasına yardımcı olmak, küresel pazarlama stratejilerinin gelişmesine destek olmak, istihdam artışı ve çalışan niteliğinin artışını desteklemek gibi farklı olumlu etkiler ortaya çıkarmaktadır. Öte yandan; şirket birleşmelerine sebep olacağı için rekabetin azalmasına neden olmak, piyasalarda baskın bir rol elde ederek haksız rekabet avantaj sağlamak, elde ettikleri karları kaynak ülkeye transfer etmek, yerel teknolojik uzmanlaşma ve bebek endüstrilerin gelişimine engel olmak, tüketimi teşvik etmek suretiyle geleneksel kültürleri erozyona uğratmak ve tek tip insan prototipi oluşmasına sebebiyet vermek, devlet oto-

OECD (2002), Foreign Direct Investment for Development - Maximizing Benefits Minimizing Costs, Paris, s.9-23; E. Lim (2001), "Determinants of, and the Relation between Foreign Direct Investment and Growth: A Summary of the Recent Literature", IMF Working Paper, No: 175, s.3; P. M. Dickie ve X. Fan (2000), "The Contribution of Foreign Direct Investment to Growth and Stability", ASEAN Economic Bulletin, Cilt: 17, Say1: 3, s.314; E. Alkin (2001), "Büyüme İstikrar Yabancı Sermaye İlişkisi”, Ekonomik İstikrar, Büyüme ve Yabancı Sermaye, Ankara: TCMB, s.14-5; I. A. Moosa (2002), Foreign Direct Investment Theory, Evidence and Practice, London: Palgrave, s.73-7; L. Çinko (2009), "Doğrudan Yabancı Sermaye Hareketlerinin Makroekonomik Etkileri”. Marmara Üniversitesi I.I.I.B.F. Dergisi, Cilt: 26, Say1: 1, s.124-5; M. R. Agosin ve R. Machado (2005), "Foreign Investment in Developing Countries: Does it Crowd in Domestic Investment?", Oxford Development Studies, Cilt: 33, Say1: 2, s. $159-60$ 
ritesine alternatif bir güç oluşturmak, enflasyonist baskı yapmak, çalışan ücretlerinin düşük kalmasına neden olmak hususları da, doğrudan yabancı sermaye yatırımlarının ev sahibi ülke nezdindeki olumsuz etkileri olarak siralanmaktadır. ${ }^{10}$

\section{DYSY'nın Gelişimi: Küresel Trend, ODKA ve İran}

Doğrudan yabancı sermaye akımlarının tarihi serüvenini Kıta Avrupası ülkelerinin 16'ncı yüzyıldaki sömürgecilik faaliyetleri çerçevesinde ekonomik faaliyetlerini farklı ülkelere/bölgelere taşımalarına kadar uzatmak mümkündür. DYSY'nin günümüzdeki öncüllerini, Sanayi Devrimi ile birlikte endüstrileşmede başı çeken ülkelerin elde ettiği sermaye birikiminin, daha yüksek getiri elde edebilmek maksadıyla ucuz işgücü ve bol hammadde bulunan ülkelere yönlendirilmesi sürecinin oluşturduğu söylenebilmektedir.

Birinci Dünya Savaşı'nın Avrupa'da ortaya çıkardığı yıkım süreci ile birlikte duraklayan doğrudan yabancı sermaye akımları, özellikle İkinci Dünya Savaşı sonrasında Amerika Birleşik Devletleri kaynaklı çok uluslu şirketler tarafindan, Batı Bloğuna eklemlenen ülkelerin çeşitli endüstri ve hizmet sektörlerine yoğunlaşarak, bu ülkelerin kalkınma hamlelerine destek olma rolüne bürünmüştür. Nihayet küreselleşme ile birlikte genişleyen ulaşım, iletişim ve teknoloji imkânları doğrultusunda, doğrudan yabancı sermaye yatırımlarının hacmi gözle görülür biçimde artmıştır. ${ }^{11}$

Grafik 1'den de izlenebildiği üzere, 1980'li yılların ortalarından itibaren GSYİH miktarı ve toplam ticaret hacmine nispeten oldukça yüksek bir artış ivmesi yakalayan doğrudan yabancı sermaye yatırımları, 1997 yılındaki Asya Mali Krizi sonrasında ve 2008 yılındaki Küresel Finans Krizi ertesinde gerilemişse de, genel anlamda artı̧s trendini devam ettirmekte ve böylece, özellikle kalkınma yolunda güvenilir/sağlam bir dış finansman desteğine ihtiyaç duyan ülkeler açısından cazip bir kaynak olma hüviyetini sürdürmektedir. ${ }^{12}$

\footnotetext{
10 C. W. Kegley ve S. L. Blanton (2015), Dünya Siyaset, - Yönelim ve Dönüşüm, Çev: H. A. Gessler, Sakarya: Sakarya Üniversitesi Kültür Yayınları, s.145-6.

11 F. Cömert (1998), "Yabancı Sermayenin Dünü, Bugünü ve Geleceği”, Hazine Dergisi, Say1: 12, s.1-3; Mucuk, a.g.m., 65-6.

12 E. Saygın (2017), Ortadoğu'da Kalkınmanın Finansmanı - Doğrudan Yabancı Sermaye Yatırımlarl ve Kurumlar, İstanbul: Pınar Yayınları, s.43.
} 
Grafik 1: Dünya'da Üretim, Ticaret ve DYSY'nın Karşılaştırmalı Analizi (1970-2016)

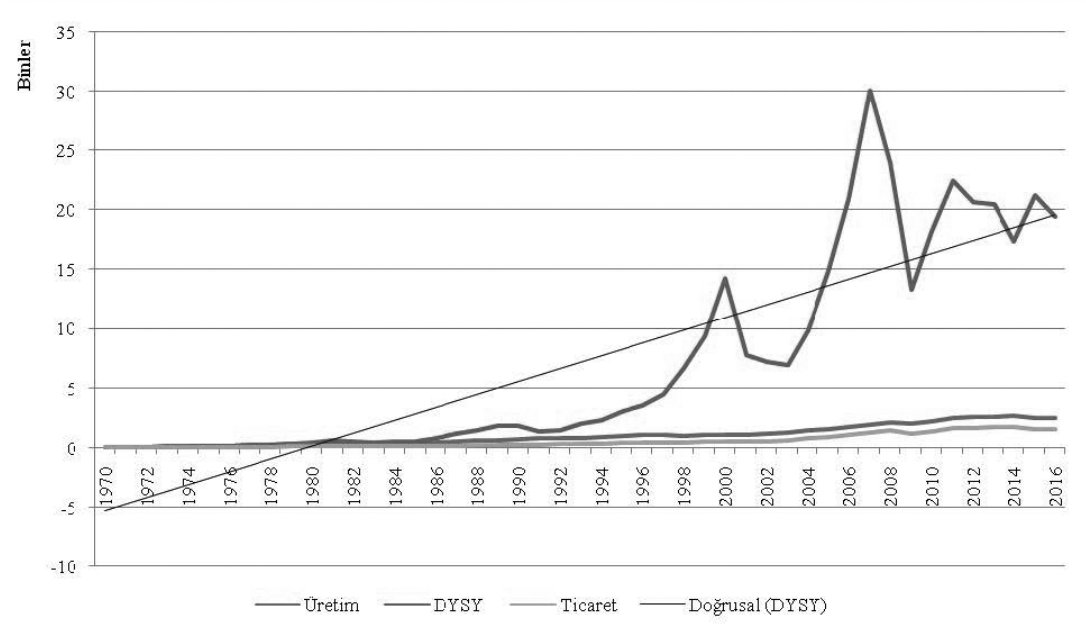

Not: $1970=100$

Kaynak: Dünya Bankası (2017). World Development Indicators, http:// databank.worldbank. org/data/reports. asports.aspx?source=World-Development-Indicators, çevrimiçi veritaban1 (Erişim: 22.10.2017).

Bu doğrultuda, İran'ın dâhil olduğu ODKA bölgesinin, doğrudan yabanc1 sermaye girişleri bakımından diğer bölgelerle/ülke gruplarıyla kıyas edildiği Grafik 2 incelendiğinde, 1990 y1lı itibarıly dünya genelinde gerçekleşen yaklaşık 205 Milyar US\$ tutarındaki DYSY akımının \%0,7'sini teşkil eden 1,6 Milyar US\$'1 ODKA'ya yönelmiş iken, 2016 yılında 1,7 Trilyon US\$ olarak gerçekleşen doğrudan yabancı sermaye akımının yaklaşık $\% 2,5$ 'ine denk gelen 44,7 Milyar US\$'lık kısmı ODKA bölgesini tercih ettiği görülmektedir.

Dünya Bankası istatistiklerine göre, Sahra-Altı Afrika ve Bağımsız Devletler Topluluğu ile birlikte küresel doğrudan yabancı sermaye akımlarının en az tercih ettiği bölge olduğu anlaşılan ODKA içerisinde yer alan İran'ın da, 2016 yılındaki yaklaşık 3,3 Milyar US\$'lık DYSY girişi performansı (Bkz. Grafik 3) ile Birleşik Arap Emirlikleri (8,9 Milyar US\$ ile bölge toplamının \%20'si), Mısır (8,1 Milyar US\$ ile bölge toplamının \%18'i) ve Suudi Arabistan'dan (7,4 Milyar US\$ ile bölge toplamının \%16's1) sonra bölgenin dördüncü en çok DYSY çeken ülkesi olduğu; ancak doğal kaynak sahipliği ve oldukça cazip bir gelişen pazar olması özellikleri karşısında hâlihazırdaki durumunun, potansiyelinin altında yer aldığı değerlendirilmektedir. 
Grafik 2: İran, ODKA ve Diğer Bölgelerde DYSY Girişlerinin Karşılaştırmalı Analizi, (1990-2016)

a) ODKA ve Diğer Bölgelerde DYSY Girişlerinin Karşılaştırmalı Analizi, US\$

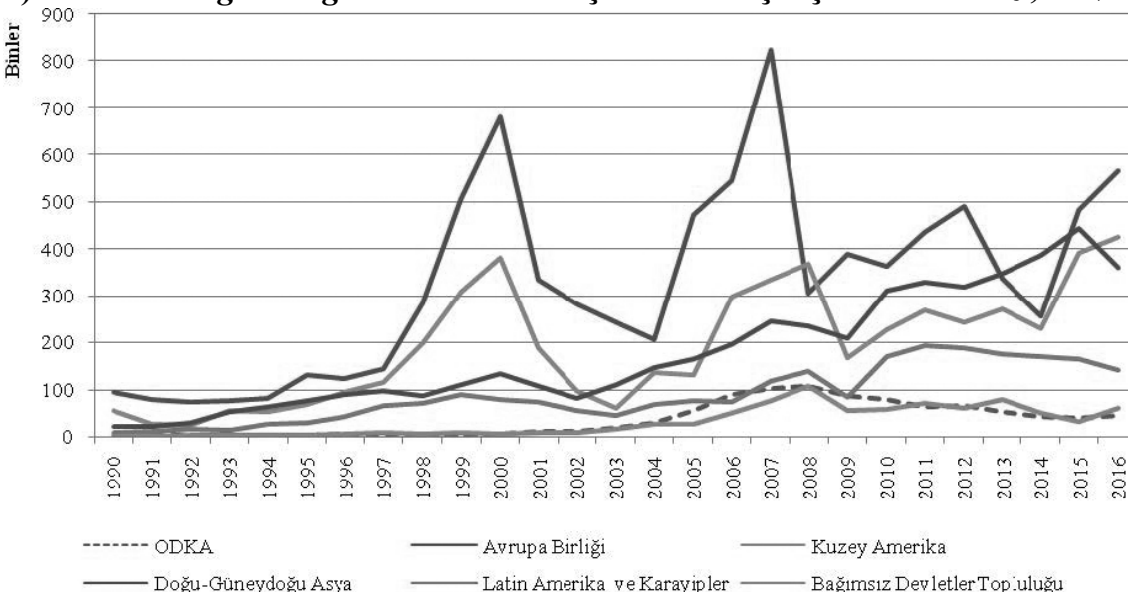

b) ODKA ve İran'da DYSYGiriş Akımlarının ve Giriş Stoklarının Karşılaştırmalı Analizi, \%GSYIH

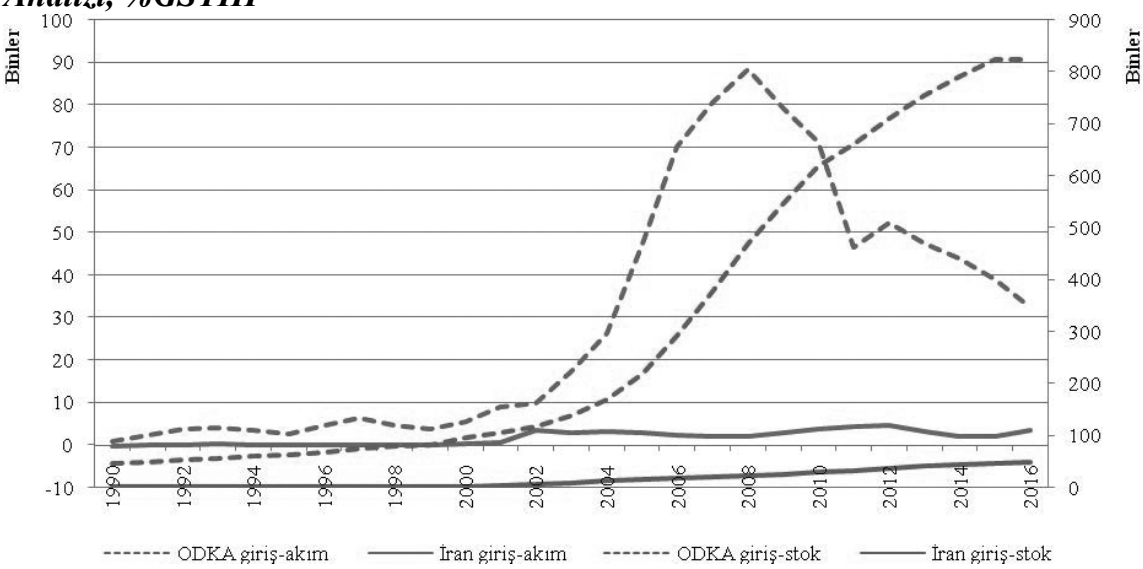

Not 1: ODKA verisi Cibuti, Fas, Lübnan, Mısır, Tunus, Ürdün, Cibuti, Fas, Cezayir, Irak, İran, Suriye, Yemen, Bahreyn, Birleşik Arap Emirlikleri, Katar, Kuveyt, Libya, Suudi Arabistan ve Umman olmak üzere Dünya Bankası tanımıyla uyumlu olarak, 18 ülkeyi kapsayacak şekilde tarafımızdan hesaplanmıştır.

Not 2: (b) bölümünde sol eksenden DYSY giriş akımları (Milyar US\$), sağ eksenden giriş stokları (Milyon US\$) izlenebilmektedir.

Kaynak: UNCTAD, Dünya Yatırım Raporu 2017: Annex Tables, http://unctad.org/en/ Pages/DIAE/World\%2 0Investment\%20Report/Annex-Tables.aspx, çevrimiçi veri taban1, (Erişim: 09.10.2017). 
2016 y1lı itibarıyla, bir önceki yıla nispeten \%500'ü geçen bir artışla dış yatırımcılar tarafindan toplam 59 proje uygulanan İran, yaptırımların da kaldırılmasıyla birlikte, 3 Milyar US\$' 1 aşan yatırımları ile başta Almanya ve İspanya menşeli dış yatırımcılar olmak üzere, Türkiye, Birleşik Arap Emirlikleri, İngiltere, İrlanda, Ermenistan, Afganistan, Belarus, Azerbaycan, Rusya, Fransa, Hollanda, Hindistan, Venezüella, Irak, Kuveyt, Malezya, Kıbris ve Ermenistan gibi ülkelerden muhtelif miktarlarda DYSY çekmektedir. ${ }^{13}$

\section{İran'da DYSY'nın Belirleyicisi Olarak Ekonomik Müşevvikler}

Ekonomik müşevvikler, genel anlamda, çok uluslu işletmelerin -kendi stratejik/davranışsal önceliklerinden başka- bir ülkede/ekonomide yatırım yapma kararı vermelerine teşvik edici yönde katkı sağlayan iktisadi faktörleri ifade etmektedir. Bu çerçevede, çalışmaya konu ev sahibi ülke olan İran'ın gayrı safi yurtiçi hasıla miktarı, milli gelir artış hızı, ortalama tüketim eğilimi ve potansiyeli, nüfus yapısı, kentleşme oranı, doğal kaynak sahipliği, üretimin sektörel yapısı, işgücünün niteliği, potansiyel ihraç pazarlığına yakınlığı gibi ekonomik müşevviklerinin sunduğu piyasa ya da piyasaya yakınlık sağlayan, doğal kaynaklara erişimi kolaylaştıran, üretimde etkinlik artına imkan verebilen ve stratejik aktif elde etme motivasyon oluşturan unsurların incelenmesi, halihazırda İran'a yönelen doğrudan yabancı sermaye akımlarının düzeyini anlamlandırmamıza yardımcı olabilecektir.

13 Financial Tribune (2017), "Iran 2nd Biggest FDI Destination in MENA", https:// financialtribune.com/articl es/domestic-economy/65339/iran-2nd-biggest-fdi-destinationin-mena, (Erişim: 13.10.2017). 
Grafik 3: İran'ın Karşılaştırmalı Milli Gelir Performansı (1970-2016)

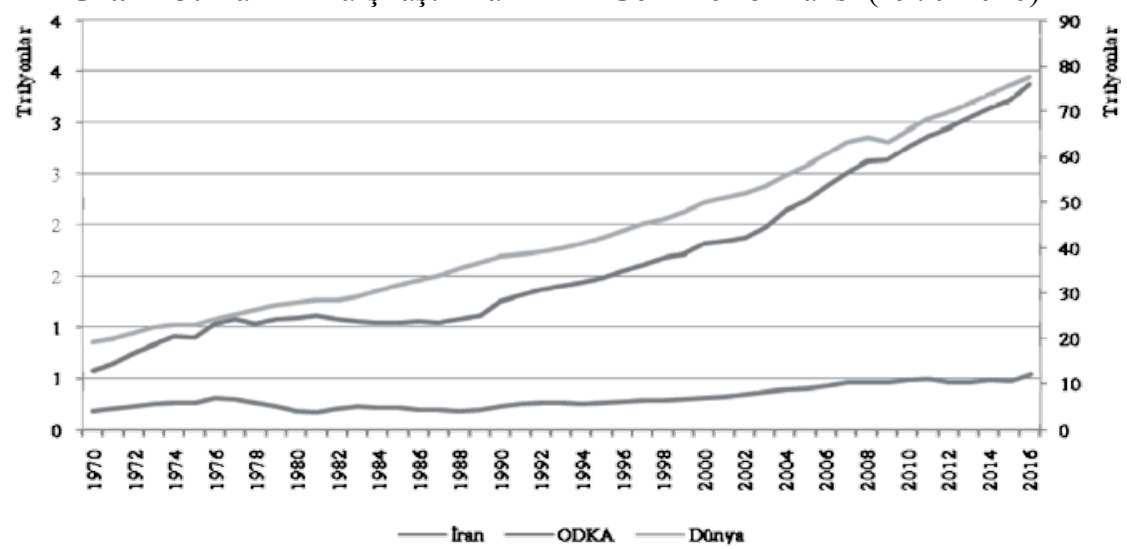

Not: Dünya geneline ait gösterge sol eksende, ODKA ve İran ise sağ eksende gösterilmektedir.

Kaynak: Dünya Bankası (2017). World Development Indicators, http://databank.worldbank. org/data/reports. asports.aspx?source=World-Development-Indicators, çevrimiçi veritaban1 (Erişim: 22.10.2017).

İran'ın, içinde bulunduğu ODKA bölgesi ve dünya geneline ait GSYİH göstergelerinin, son kırk altı y1lı kapsayacak şekilde ve karşılaştırmalı olarak sunulduğu Grafik 3'e bakıldığında, 1970 yılında 19 Trilyon US\$ civarındaki toplam küresel üretim 2016 yılı itibarıyla 4 katına çıkarak 78 Trilyon US\$ olurken ve aynı süreçte benzer bir trend izleyen ODKA bölgesinin GSYIH miktarı da 600 Milyar US\$'dan neredeyse 6 katına ulaşıp yaklaşık 3,5 Trilyon US\$'a yükselir iken; İran'ın GSYİH miktarı, 180 Milyar US\$'dan ancak üç katına, yani 540 Milyar US\$'a çıkabilmiştir.

Bu durumun kökenleri, Mahdavy'nin, İran İslam Devrimi’nin gerekçelerini temellendirmeyi amaçlayan ve esasen söz konusu gerekçeler ortadan kalkmadığı cihetle günümüz İran'ının durumuna da 1şık tutarak güncelliğin koruyan 'Rantiyeci Devletlerde Ekonomik Gelişmenin Yapısı ve Problemleri: İran Örneği' başlıklı çalışmasında bulunabilir. ${ }^{14}$ Öyle ki daha sonraları ODKA bölgesindeki doğal kaynak zengini neredeyse bütün ülkelerde devlet-toplum-piyasa ilişkilerini açıklamak üzere sıklıkla referans verilen

14 H. Mahdavy (1970), "The Patterns and Problems of Economic Development in Rentier States: The Case of Iran", Der: M. A. Cook (Ed.), Studies in the Economic History of the Middle East-From the Rise of Islam to the Present Day, Oxford: Oxford University Press, s.428-67. 
rantiyeci devlet teorisi, kamu gelirlerinin ağırlıklı bir kısmının enerji kaynakları ihracından sağlandığı ve elde edilen bu kaynağın sınırlı bir kısmının -kuşkusuz politik sistemin belirlenimine ve devamlılığına yönelik siyasal haklarından hatırı sayılı ölçüde feragatleri sonrasında- transfer harcamaları vasıtasıyla halk ile paylaşıldı̆̆ı zımni bir anlaşma zemininin varlığını işaret etmektedir. Demokrasi teorisinin üzerine temellendiği vergi-temsil dengesinin, bahse konu rantiyer ilişki biçimi nedeniyle sağlıklı bir zemin bulamadığı İran'da, makro ekonomik politikaların işlevselliği ve dolayısıyla da GSYİH hacminin potansiyelinin oldukça altında bir performans kaydetmesi şaşırtıcı olmamıştır. Ve fakat 80 milyonu bulan nüfusu ve yarım trilyon doları aşan GSYİH miktarı ile İran, oldukça cazip bir gelişen pazar olma hüviyeti taşımaktadır.

Karşılaştırmalı ekonomik büyüme performansını gösteren Grafik 4 incelendiğinde İran, genel olarak küresel ortalama büyüme oranının istikrarlı yapısına yakınlaşamadığı gibi ODKA bölgesinin -enerji fiyatlarıyla bağlantılı trendini de aşacak şekilde istikrarsız ve düşük bir performans sergilemektedir. İran'ın, 1990-2000 döneminde ortalama \%2,4 (Dünya: \%2,9 ve ODKA: \%3,8), 2000-2009 arasında ortalama \%5,5 (Dünya: \%3,2 ve ODKA: 5,3), 2010-2015 periyodunda ise \% 0,2 (Dünya: 2,9 ve ODKA: 3,3 ) olarak gerçekleşen büyüme performansının ${ }^{15}$, bu ülkenin toplam ihracatının 2/3'ünü aşan kısmının doğal kaynaklara dayanmasıyla doğrudan bağlantılı olduğu anlaşılmaktadır. ${ }^{16}$

İran'da ekonomik performansın istikrarsız seyri ile fiyat genel düzeyinin istikrarsızlığı (enflasyon), yüksek işsizlik oranı, düşük yurtiçi tasarruf oranı gibi makroekonomik göstergeler arasında karşılıklı ve birbirini besleyen bir ilişki görülmekte; bu kısırdöngü soysal ve iktisadi hayatı olumsuz yönde etkilemektedir. Örneğin, Devrim'den bu yana İran ekonomisinin en kronik sorunu olarak görülen, esasen enerji fiyatlarındaki konjonktürel dalgalanmalar ile bağıntılı seyreden ve halen de -İran özelinde- etkin bir mücadele yöntemi geliştirilemeyen yüksek ve dalgalı enflasyon, sebep olduğu belirsizlik ve güvensizlik dolayısıyla risk algısını yükseltmekte; kur ve faiz

15 Dünya Bankas1 (2017), World Development Indicators 2017, s.68-72.

16 K. Ahmed ve Diğerleri (2016), "Dynamics between Economic Growth, Labor, Capital and Natural Resource Abundance in Iran: An Application of the Combined Cointegration Approach", Resources Policy, Say1: 49, ss.213-21; Dünya Ticaret Örgütü (2017), Trade Profiles 2017, s.172. 
riskleri nedeniyle hem iç hem de dış yatırımcıların uzun dönemli yatırım kararları almalarına engel olmaktadır. ${ }^{17}$

Grafik 4: İran'1n Karşılaştırmalı Ekonomik Büyüme Performansı (1970-2016)

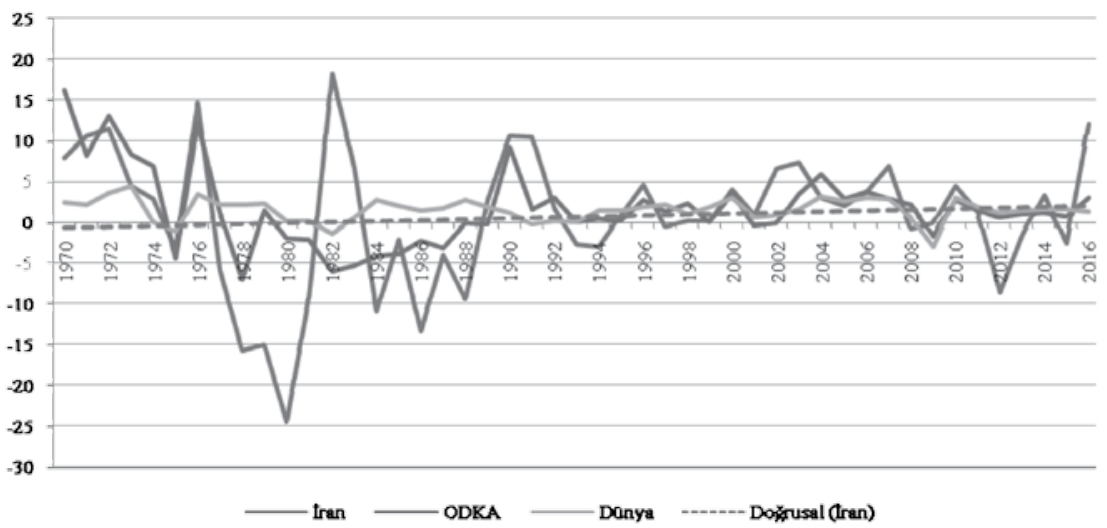

Kaynak: Dünya Bankas1 (2017). World Development Indicators, http://databank.worldbank. $\mathrm{org} / \mathrm{data} /$ reports. asports.aspx? source=World-Development-Indicators, çevrimiçi veritabanı (Erişim: 22.10.2017).

İran'ın çok uluslu işletmeler açısından yatırım yapılabilir ülkeler kategorisinde değerlendirilmemesinin bir diğer belirleyici unsuru olarak tercih edilen kontrollü döviz kuru rejimi ile yeterli derinliği, genişliği ve esnekliği bulunmayan bankacılık ve finans sektörünü ifade edebiliriz. Kontrollü döviz kuru rejimi nedeniyle yerli para aşırı değerlenmekte ve bu da hem dış ticaret dengesinin bozulmasına hem de ihracat ahenginin enerji ürünleri lehine bozulmasına sebep olmaktadır. ${ }^{18}$ Bunun yanında, Devrim sonras1 süreçte siyasal yönetimin ideolojik seçimleri etrafında millileştirme ve kamulaştırma uygulamaları ve sınır-dışı iş ve işlemleri sonlandırılması, hâlihazırda İran'ın verimsiz bankacılık sektörü ve daralan kredi/finans piyasasının şekillenmesinde önemli rol oynamıştır. ${ }^{19}$ Para, sermaye finans ve kredi piyasalarına ilişkin dışlayıcı/müdahaleci hukuki düzenlemeler ve

17 M. Aslan (2016), Iran'da Enflasyon Sorunu, İRAM Analiz, No: 1, s.3-4.

18 Aslan, A.e., s.4.

19 K. Karamelikli ve N. Alizadeh (2017), "İran İslami Bankacılık Sistemi Üzerine Bir Değerlendirme", Bankacılık ve Sigortacılık Araştırmaları Dergisi, Cilt: 2, Sayı: 11, s.56. 
rekabete kapalı yapı, çok uluslu işletmelerin gerçekleştirmeleri muhtemel bankacılık ve kambiyo işlemleri ile kredi ve finansman imkânları üzerinde yoğun baskı ortaya çıkaracağı cihetle yatırım kararları üzerinde olumsuz etkide bulunmaktadır.

Tablo 2: İran'ın Çeşitli Makro Ekonomik ve Kalkınmışlık Göstergeleri (2000-2016)

\begin{tabular}{|l|r|r|r|}
\hline Göstergeler & $\mathbf{2 0 0 0}$ & $\mathbf{2 0 0 8}$ & $\mathbf{2 0 1 6}$ \\
\hline Kişi Başına Milli Gelir (Cari Fiyatlarla, US\$) & $1.657,17$ & $5.574,41$ & $5.219,10$ \\
\hline Dışa Açılık Oranı (\%) & 41,26 & 48,23 & 43,21 \\
\hline Enflasyon (Tüketici Fiyatlarıyla) & 14,48 & 25,55 & 8,57 \\
\hline İşsizlik (\%) & 11,80 & 10,50 & 11,40 \\
\hline Yurtiçi Tasarruf Oranı (\%GSYİH) & 36,78 & 46,68 & 37,29 \\
\hline Toplam Doğal Kaynak Rantı (\%) & 31,14 & 33,58 & ${ }^{*} 24,29$ \\
\hline Toplam Yaşam Beklentisi (Yil) & 70,14 & 73,07 & $* * 75,74$ \\
\hline
\end{tabular}

* 2014 y1l1 verisidir.

** 2015 y1l verisidir.

Kaynak: Dünya Bankası (2017). World Development Indicators, http://databank.worldbank. org/data/reports. asports.aspx?source=World-Development-Indicators, çevrimiçi veritabanı (Erişim: 22.10.2017).

Diğer taraftan, İran'da hızla artan şehirleşme ile birlikte gelecek kaygısı güden genç kuşakların öncelikle eğitim, sonrasında ise istihdam olanakları beklentisi ön plana çıkmaktadır. Nüfusunun 3/4'ü şehirlerde yaşayan ve 2/3'ü 40 yaş altında bulunan İran'da bahse konu dinamik nüfus yapısı, sistemin kurucu kodlarına daha yakın olan kişilerin aksine siyasal karar mekanizmalarına katılım yönünde talepleri öne çıkarmaktadır. Bu durum toplumsal barış ortamının devamlılı̆̆ını tehdit etme potansiyelini barındırmaktadır. ${ }^{20}$ Kaldı ki çok uluslu işletmelerin en azından bir kısım üst ve orta düzeyde yönetim kademesinin kaynak ülkeden ev sahibi ülkeye geleceği ve bu kişilerin ev sahibi ülkenin yaşam standartlarını göz önünde bulunduracağı gerçeği karşısında, plansız kentleşme ile birlikte yaşam kalitesini belirleyen mesela hava kirliliğinin yüksek düzeyde bulunması, günlük hayatta kadınlara yönelik kılık-kıyafete dair zorlayıcı uygulamalar ve internete erişim üzerindeki engeller ile benzeri etmenler nedeniyle olumsuz bir intiba oluşturacağı muhakkaktır.

20 M. Koç ve S. Afacan (2016), İran'da Değişimin Dinamikleri, İRAM Perspektif, No: 1, s.6. 
İran'ın ülke-içi dinamiklerinden kaynaklanan negatif unsurlardan başka, bölgesel ve küresel ilişkilerinden neşvü nema bulan bazı olumsuzluklar bulunmaktadır. İkinci Dünya Savaşı sonrasında Amerika Birleşik Devletleri (ABD) ile çok yönlü ilişkileri bunan İran, Devrim'den sonra bağlantısızlık politikasına dönerek ABD hâkimiyetinden kurtulma yönünde adımlar atmış, öte yandan tercih ettiği mezhepsel-yayılmacı politika nedeniyle ODKA bölgesi ülkeleriyle de sağlıklı ilişkiler kurmayı başaramamış ve Devrim-sonrası süreçte bir taraftan kendi iç problemleriyle mücadele ederken, diğer taraftan da zaman zaman dozu değişmekle birlikte sürekli olarak ekonomik ve politik yaptırımlara muhatap olmuştur. ${ }^{21} \mathrm{Bu}$ doğrultuda, küreselleşme sürecinin genel trendinin ${ }^{22}$ aksine belirgin bir özelleştirme politikası uygulamayan ${ }^{23}$ İran'da, bilakis ekonomide devletçi anlayışın tercih edilmesi ve millileştirme uygulamaları sonrasında, çoğunlukla verimsiz iş süreçlerine sahip ve iktisadi hayatın diğer fazlarına da bu olumsuz özelliğini yansıtan kamu sektörünün ekonomi içerisindeki hacmi oldukça büyümüş ve bu durum yakın zamanda deklare edilen İran'ın 'direniş ekonomisi doktrini' penceresinden pek de problemli bir nokta olarak görülmemiştir. ${ }^{24}$ Şöyle ki İran ekonomisinin kronik problemlerini aşmaya matuf birçok hedefi içeren direniş ekonomisi doktrininin metninde ${ }^{25}$ Devrim sonrası oluşan siyasal yapının kendisini koruma reflekslerinin yansımaları hissedilmekte

21 T. Arı (1999), 2000'li Yıllarda Basra Körfezinde Güç Dengesi, 4. Baskı, İstanbul: Alfa Basım, s.37-8.

22 Küreselleşme ile birlikte Dünya Bankası, IMF, Dünya Ticaret Örgütü gibi uluslar arası ekonomik kuruluşlar demokratikleşme, hukuk devleti, yönetişim, etkin bürokrasi, deregülasyon ve özelleştirme gibi 'değer'lerin dönüşümü ve kapalı sistemlerin tedbirlerin azaltılması suretiyle ekonomik aktivitenin liberalleşmesini içeren reform önerilerinde bulunmuştur. Bkz. N. Saygılıoğlu ve S. Arı (2002), Etkin Devlet Kurumsal Bir Tasarl ve Politika Önerisi, İstanbul: Sabanc1 Üniversitesi Yayınları s.2730).

23 Dünya Bankası kayıtlarına göre 1988-1999 döneminde hiçbir özelleştirme yapılmamışken, 2000-2008 periyodunda telekomünikasyon sektöründe toplam $\sim 720$ Milyon US\$ tutarında iki özelleştirme yapılmıştır. (Bkz. Dünya Bankası (2017). Privatization Database (1990-2008), http://data.worldbank.org/datacatalog/pr ivatization-database, çevrimiçi veritabanı (Erişim: 22.10.2017)).

24 R. Yanar (2015), "İki Ateş Arasında İran Ekonomisi”, Ortadoğu Analiz, Cilt: 7, Sayı: 67, s.90; H. K. Aslan (2016), Iran'in Orta Asya Politikası (1991-2016), İRAM Analiz, s.10-2; S. Berber (2013), "İran'ın Ekonomi Politikas1, Yaptırımların Etkisi ve İkilemler", Bilge Strateji, Cilt: 5, Sayı: 9, s.74-5.

25 İlgili metin, İran Araştırmaları Merkezi (İRAM) tarafından Türkçeye tercüme edilmiştir. (Bkz. https://iramcenter.org//d_hbanaliz/Yranda-DireniY-EkonomisiDoktirini.pdf). 
ve bu doğrultuda devlet/kamu odaklı bir yöntem tarzının zaruri görüldüğü anlaşılmaktadır.

Büyük endüstrilerde kamu hâkimiyetinin bulunduğu, merkezi planlama ile yönetilen karma ve rant-odaklı bir ekonomik yapıya sahip olması dolayısıyla üretim miktarı ve dolayısıyla da gelir düzeyi ve tüketim artışı sınırlı düzeyde kalan ${ }^{26}$ İran, doğrudan yabancı yatırımı yapma kararı verecek olan çok uluslu işletmeleri, gelişmekte olan piyasa hacmi ve tüketime temayülü yüksek olan genç nüfusu ile potansiyel ihraç pazarlarına yakınlığ yısıyla pazar-motivasyonlu olarak cezbetmekte; ancak sahip olduğu doğal kaynakların devlet kontrolünde olması ve başta enflasyon olmak üzere kambiyo, bankacılık ve finans sektöründeki kısıtlamaların etkisiyle oluşan ekonomik istikrarsızlıklar nedeniyle kaynak-motivasyonlu ve etkinlik-motivasyonlu çok uluslu işletmeler açısından teşvik edici/ön açıcı unsurlar barındırmamaktadır.

\section{İran'da DYSY'nın Belirleyicisi Olarak Kurumsal Yapı}

Kurum kavramı, en popüler şekliyle, 'insanlar arasındaki ilişki formlarını belirleyen ve yine insanlarca oluşturulmuş kisitlamalar, yani bir toplumda oynanan oyunun kuralları' olarak tanımlanmaktadır. ${ }^{27}$ Kurumsal İktisat Okulu'nun kurucusu olarak kabul edilen Veblen tarafindan 'toplumların, yaşamlarını sürdürebilmek için, çevreyle ilişkileri dâhilinde geliştirdikleri alışkanlıklar' olarak geniş ölçekte tanımlanan kurum kavramı, ${ }^{28}$ Yeni Kurumsal İktisat Okulu ${ }^{29}$ temsilcilerince 'olası keyfilikleri ve firsatçı davra-

26 C. Pierce (2008). Corporate Governance in the Middle East and North Africa, London: GMB Publishing, s.124.

27 D. C. North (2001), Kurumlar, Kurumsal Değişim ve Ekonomik Performans, Çev: G. Ç. Güven, İstanbul: Sabancı Üniversitesi Yayınlan, s.9.

28 T. B. Veblen (1994), The Theory of Leisure Class, Dover Thrift Editions, Canada: G. Publishing Co., s.120.

29 20'nci yüzyılın başında anaakım iktisadın rağmına özellikle Amerika Birleşik Devletleri'nde gelişen tepkiler ekseninde şekillenen ve günümüzde Eski Kurumsal İktisat Okulu olarak isimlendirilen akım genel olarak, tekelci şirketleri, sendikal oluşumları, devletin iktisadi etkinliklerini ve belirsizliğin neden olduğu ekonominin denge dışı seyrini kurumsallaştırmayı amaçlamak suretiyle esasen anaakım iktisada köklü bir karşı çıkışı ifade etmektedir. Diğer taraftan Yeni Kurumsal İktisat ekolü ise aynı okulun bir parçası olmakla birlikte, anaakım iktisada kökten bir karşı çıkış iddiasını ter edip rasyonalite ve tam bilgi gibi gerçekçi olmayan varsayımlar yerine işlem maliyetleri, mülkiyet hakları, eksik sözleşmeler gibi kurumsal açıklayıcıları 
nışları sınırlandirmak amacıyla insanlar tarafindan geliştirilen kurallar bütünü’ gibi daha spesifik alanları işaret edecek biçimde açılanmaktadır. ${ }^{30}$

Toplumların tabi oldukları anayasa, kanun, düzenlemeler ve sair yazılı kurallar ile tarihi süreklilik bağlamında devam edegelen örf, gelenek ve benzeri enformel alışkanlıklarının tamamını ifade eden kurumsal yapının, genel olarak ülkeler arası ekonomik gelişme farklılıklarını kapsamlı olarak açıkladığı, konumuz özelinde ise çok uluslu şirketlerin yatırım kararları üzerinde önemli belirleyicilerden olduğu cihetiyle, kapsayıc1lık ve/veya dışlayıcılık ${ }^{31}$ taşıyan bileşenlerinin ayrıca tetkik edilmesi önem arz etmektedir.

Bu doğrultuda, tematik olarak belirtecek olursak, sivil yaşamın çerçevesini belirlemek kaydıyla hayat kalitesine ve toplumsal güven ilişkilerine bilvasıta etki eden temel hak ve özgürlükler ile basın, örgütlenme ve benzeri hürriyetlerin varlığı, siyasal hakların sınırlarını çizen ve kişilerin/özel kurumların gelecek vizyonlarını ve beklentilerini şekillendiren yönetim biçimi ve politik uygulamalar, özellikle yatırımcıların karar verme süreçlerini doğrudan etkileyen mülkiyet hakları güvencesi ve etkili bir sözleşme hukuku altyapısı, iş yapma süreçlerindeki sürat ve maliyeti yansıtması açısından yolsuzluk ve bürokrasi düzeyleri ile bütün bu kurumsal yapıların adeta teminatı olan hukukun üstünlüğ̈̈ algısı ve destekleyici bir unsur olarak etkin bir asli sistemin teşkilatlandırılmış olması hususlarının İran İslam Cumhuriyeti Anayasası'ndaki, ilgili yasal çerçevedeki, ikili ve çok taraflı yatırım anlaşmalarındaki hükümlere nasıl konu edildiği ve yakın dönemde yatırım ikliminin iyileştirilmesine matuf ne çeşit reformlar gerçekleştirildiği ve bu bağlamda İran'ın en sorunlu alanlarının ne tür bir dönüşüme uğradığı/uğramadığı, kapsamlı ya da spesifik tespitler içeren açıklayıcı endeksler üzerinden gözden geçirilecektir.

katıp, geleneksel iktisat alanında karşımıza çıkan piyasa ve firma gibi unsurların işleyişinin de kurumsal süreç içerisinde değerlendirilmesi gerektiği şeklindeki savları ileri sürmekte ve bu şekilde adeta yerleşik iktisadın reformist bir tamamlayıcısı olarak görülmektedir. (Yeni Kurumsal İktisat Okulu hakkında detaylı bilgi için bkz. T. Çetin (2012), "Yeni Kurumsal İktisat", Sosyoloji Konferanslarl, No: 45, ss.43-73).

30 W. Kasper ve M. E. Streit (1998), Institutional Economics: Social Order and Public Policy, Cheltenham: Edward Elgar Publishing, s.28.

31 D. Acemoğlu ve J. A. Robinson (2013), Ulusların Düşüşü - Güç, Zenginlik ve Yoksulluğun Kökenleri, 1. Baskı, Çev: F. R. Velioğlu. İstanbul: Doğan Kitap, s.74-7. 
Resmi adiyla İran İslam Cumhuriyeti (Islamic Republic of Iran), 1979 yılında yaşanan Devrim süreci ertesinde yürürlüğe konulan ve bilahare 1989 y1lında muhtelif revizyonlara tabi tutulan anayasa ile yönetilmektedir. ${ }^{32}$ Anayasaların bir ülkedeki siyasal sistemin şeklini tayin eden temel metinler olduğu göz önünde bulundurulduğunda, İran Anayasa'nın 2'nci maddesi 'velayet-i fakih' olarak adlandırılan 'devrim rehberin'nin, ülkeni siyasal sisteminin adeta kilit taşı olduğunu ifade etmekte ${ }^{33} ; 57$ 'nci madde, ${ }^{34}$ yasama, yürütme ve yargı erklerini, çalışmalarını devrim rehberinin gözetiminde sürdüreceklerini hükme bağlamakta; devrim rehberinin görev ve yetkilerinin sıralandığ 110 'uncu madde ${ }^{35}$ ise ülkenin genel politikaların belirlenmesi ve kritik kurum ve kuruluşların yöneticilerinin atanmasında devrim rehberine oldukça geniş bir inisiyatif bırakılmaktadır. ${ }^{36}$ Her ne kadar Anayasa'da kuvvetler ayrılığına dair düzenlemelere yer verilmiş ise de genel olarak siyasal sistemin bir kişi/makam üzerine kurgulandığ İran örneğinde hem siyasal karar alma mekanizmalarının katılımcı ve çoğulcu niteliğinden, hem de yönetimin devamlılı̆̆ından/öngörülebilirliğinden emin olunamadığ cihetle, çok uluslu şirketlerin yatırım kararları üzerinde olumsuz etki doğurmaktadır. ${ }^{37}$

Nüfus yapısı itibarıyla oldukça fazla etnik azınlığa/gruba olabildiğince sükûnetle ev sahipliği yapmayı başarabilen İran'ın, sivil haklar, kadın hakları, genç özgürlükleri ya da temel hak hürriyetlerin sınırı konusunda aleyhte aşırı gitmesi ilk bakışta ironik gözükebilmektedir. Bu noktada İran'ın ulusal kimlik inşasının üzerine temellendiği ulusal düzeyde köklü farisi geçmişin, bölgesel planda şii-mezhepsel inancin ${ }^{38}$ ve küresel alanda

32 Comperative Constitution Project (2017). Iran's Constitution of 1979 with Amendments through 1989, Oxford University ve Hein Online, http://www.constituteproject.org, (23.11.2017).

33 A. Yeğin (2013), İran Siyasetini Anlama Kllavuzu, SETA Rapor, No: 23, s.53.

34 Comperative Constitution Project, a.g.e., s.20.

35 Comperative Constitution Project, A.e., s.29-30.

36 İlgili anayasa maddelerinin Türkçe çevirisi için bkz. A. Yeğin (2013), Iran Siyasetini Anlama Kılavuzu, SETA Rapor, No: 23, s.53-4.

37 Ampirik literatürden örnekler için bkz. A. Brunetti (1997), "Political Variables in Cross-Contry Growth Analysis", Journal of Economic Surveys, Cilt: 11, Say1: 2, s.16390.

38 Özellikle Suudi Arabistan ile gerginliği işaret eden bu hususa ve etkilerine dair detaylı bilgi için bkz. İnat, K. ve Diğerleri (2016). Iran - Suudi Arabistan Rekabetinin Bölgesel Etkileri, SETA Analiz, Sayı: 148. 
-özellikle Devrim sonrası süreçte oluşan- Batı karşıtlı̆̆ ve/veya Batı'dan dışlanmışlığın göz önünde bulundurulması önem taşımaktadır. Bütün bu değer/inanç sistemi üzerine kurulu olan İran'da, Devrim'in kurucu ideolojisi etrafinda şekillenmiş bulunan mevcut siyasal yapının muhafaza edilebilmesi maksadıyla devlet refleksi ağır basmakta ve bu bağlamda Anayasa'da özgürlük-güvenlik dengesi, güvenlik aleyhine bozulmuş bir görünüm arz etmektedir. ${ }^{39} \mathrm{Bu}$ durum, İran'ın uluslararası toplum nezdindeki imajını sarstığından, çok uluslu şirketlerin yatırım kararlarına negatif yönde tesir etmektedir.

Öte yandan İran'da yazılı ve görsel medya devletin sık1 kontrol ve denetiminde bulunmakta, internet ve uydu kullanımı ise ciddi kısitlamalara tabi tutulmaktadır. Kuşkusuz bütün bu kısıtlamalar karşısında özellikle görsel iletişim araçlarının 'kayıtdışı' ya da 'yeraltı' olarak nitelendirilebilecek şekilde devletin kontrolünden kaçınarak bir şekilde erişilebilir olduğu bilinmekteyse de, esasen kamusal alana hitap ettiğinden dolayı daha fazla göz önünde bulunmakta olan yazılı medyaya ilişkin kısıtlama ve kapatma uygulamaları İran'daki basın özgürlügüü algısını zayıflatmaktadır. ${ }^{40}$ Bütün bu ahval, uluslararası yönetişim ve özgürlük endekslerine de yansımıştır. Ekonomist Dergisi'nin yıllık olarak yayımladığı Demokrasi Endeksi'ne göre ODKA ülkelerinin 13'ü otoriter rejim nitelendirilmekte; keza İran'da, 2,34/10,0 skoruyla 167 ülke içinde 154'üncü sırada bulunmakta ve otoriter rejim tipinde tasnif edilmektedir. Yine Freedom House'un Basın Özgürlügü Endeksi'nde İran 199 ülke içinde 190'ıncı sırada yer almakta; keza Internet Özgürlüğü Endeksi’nde de ‘özgür olmayan' ülkeler kategorisinde bulunmaktadır. ${ }^{41}$

Sivil ve siyasal hak ve özgürlüklerden başka, mülkiyet hakların yönelecek millileştirme ve/veya kamulaştırma/el koyma ihtimalinin de doğrudan yabancı sermaye yatırımı yapacak çok uluslu işletmelerin kararlarını olumsuz yönde etkilediği bilinmektedir. ${ }^{42} \mathrm{Bu}$ noktada en garantili hükümler yine

39 H. Katouzian ve H. Şahidi (2011), “21. Yüzyılda İran - Siyaset, Ekonomi ve Çatışma”, 21.Yüzyılda İran, Çev: P. Güven, Ankara: Sitare Yayınları, s.29-31.

40 Yeğin, a.g.e., s.75.

41 Ekonomist (2016), Economist Intelligence Unit's Democracy Index 2016 - Revenge of the "deplorables", s.10 ve 43; Freedom House (2016), Freedom on the Net 2016, s.29.

42 M. Azzimonti ve P. G. Sarte (2007), "Barriers to Foreign Direct Investment under Political Instability", Economic Quarterly, Cilt: 93, Say1: 3, s.287-315. 
anayasalarda yer almak durumundadır. İran Anayasası'nın 22'nci madde$\mathrm{si}^{43}$ diğer temel haklar ile birlikte mülkiyet hakkının da dokunulamaz olduğunu garanti altına almış ancak 'yasanın hariç tuttuğu durumlar' kaydını düşmektedir. Bu husus, anayasa gibi üzerinde değişiklik yapılması daha zor olan ve bu yönüyle yatırımcılar nezdinde daha güvenilir bir düzenleme ile garanti altına alınmış kritik bir hakkın, sınırları belirlenmemiş/ucu açık şekilde siyasal yönetimin günübirlik ilişkileri bağlamında değişikliğe uğrayabilecek politikalarının inisiyatifine bırakılması sonucunu doğurmuştur. Keza İran Anayasası'nda maddi/fikri mülkiyet hakkının ne şekilde transfer dileceğine ya da bu hakka dair uyuşmazlıkların ne şekilde çözümleneceğine dair bir hüküm de bulunmamaktadır. Bu bağlamda, Uluslararası Mülkiyet Hakları Birliği’nin her yıl düzenli olarak yayımladığı Uluslararası Mülkiyet Hakları Endeksi'nde İran'ın son yirmi ülke içerisinde bulunduğu ve İran'daki büyük işletmelerin neredeyse tamamına yakınının kamu kontrolünde olduğu nazarı itibara alındığında, mülkiyet haklarının korunmasına dair mezkûr gevşek/muğlâk/ucu açık düzenlemelerin dahi, her an millileştirme ve/veya kamulaştırma riskine muhatap olma ihtimali bulunan çok uluslu işletmelerin yatırım kararlarını olumsuz etkileyebileceği açıktır.

İran'ın küresel doğrudan yabancı sermaye akımlarını cezbedebilmesi önündeki bir diğer önemli kurumsal kısıt da bürokratik etkinliğin bulunmaması ve yolsuzluk algısının yüksek düzeyde seyretmesidir. Uluslararası Şeffaflık Örgütü'nün yayımladığı Yolsuzluk Algısı Endeksi'ne göre İran, 29/100 puan ile 176 ülke içerisinde 131'inci sırada yer almaktadır. Yine Dünya Bankası tarafından, kamusal hizmetlerin niteliği ve siyasala bask1lardan bağımsızlığı algısını ölçek maksadıyla $-2,5$ ile $+2,5$ arasında belirlenen yönetimin etkinliği skoru kapsamında İran, $-0,20$ puan ile oldukça kötü bir pozisyonda bulunmaktadır. Bu durumun temel olarak, siyasal kurumların katılımcılık ve hesap verebilirlik düzeylerinin düşük olmasının idareye ve kamu iktisadi teşebbüslerine verimsizlik ve yolsuzluk olarak önemli bir yansıması olarak kabul edilmelidir. Dolayısıyla siyasal etkiden arındırılmış bir bürokratik yapının henüz tesis edilememiş olması nedeniyle, iş süreçlerinde yavaş, maliyetli ve kayıtdışı ilişkilere mahkûm olunabileceği endişesi, çok uluslu işletmelerin doğrudan yabancı sermaye yatırımı kararları üzerinde negatif tesirde bulunabilecektir.

43 Comperative Constitution Project, a.g.e., s.14. 
Tablo 3: İran'da Kurumsal Kalite Göstergeleri (2016)

\begin{tabular}{|c|c|c|c|c|c|}
\hline & Kurum/Endeks & Gösterge & $\begin{array}{l}\text { Ölçüm Aralığı } \\
\text { (En Düşük/En } \\
\text { Yüksek) } \\
\end{array}$ & Skor & Sira \\
\hline \multirow{6}{*}{ 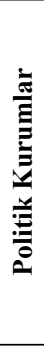 } & Freedom House/ & Sivil Haklar & \multirow{2}{*}{$7 / 1$} & 6 & - \\
\hline & Dünyada Özgürlük Endeksi & Politik Haklar & & 6 & - \\
\hline & \multirow{2}{*}{$\begin{array}{l}\text { Dünya Bankasi// } \\
\text { Dünya Yönetişim Göstergeleri }\end{array}$} & \multirow{2}{*}{$\begin{array}{l}\text { Ífade Özgürlüğü ve } \\
\text { Hesap Verilebilirlik } \\
\text { Siyasal İstikrar ve } \\
\text { Șiddetsizlik } \\
\end{array}$} & \multirow{2}{*}{$-2,5 /+2,5$} & $-1,39$ & - \\
\hline & & & & $-0,74$ & - \\
\hline & $\begin{array}{l}\text { Ekonomist Dergisi/ } \\
\text { Demokrasi Endeksi }\end{array}$ & Demokrasi Seviyesi & $1 / 10$ & 2,34 & $154 / 167$ \\
\hline & \begin{tabular}{|l} 
Freedom House/ \\
Basın Özgürlüğü Endeksi \\
\end{tabular} & Basın Özgürlüğü & $100-0$ & 90 & 190/199 \\
\hline \multirow{3}{*}{ 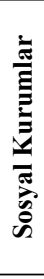 } & $\begin{array}{l}\text { Uluslararası Şeffaflık Örgütü/ } \\
\text { Yolsuzluk Algılama Endeksi }\end{array}$ & Yolsuzluk Düzeyi & $0-100$ & 29 & $131 / 176$ \\
\hline & $\begin{array}{l}\text { Uluslararası Mülkiyet Hakları } \\
\text { Birliği/ } \\
\text { Uluslararası Mülkiyet Hakları } \\
\text { End. } \\
\end{array}$ & $\begin{array}{l}\text { Mülkiyet Hakları } \\
\text { Güvencesi }\end{array}$ & $0-10$ & 4,24 & $\begin{array}{l}\text { Son } 20 \\
\text { ülke } \\
\text { içinde }\end{array}$ \\
\hline & $\begin{array}{l}\text { Dünya Bankası// } \\
\text { Dünya Yönetișim Göstergeleri }\end{array}$ & Hukukun Üstünlüğü & $-2,5 /+2,5$ & $-0,71$ & - \\
\hline \multirow{6}{*}{ 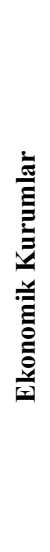 } & $\begin{array}{l}\text { Heritage Vakfı ve WSJ/ } \\
\text { Ekonomik Özgürlük Endeksi }\end{array}$ & $\begin{array}{l}\text { Ticari Özgürlüğü } \\
\text { Parasal Özgürlük } \\
\text { Finansal Özgürlük } \\
\text { Yatırım Özgürlüğü } \\
\text { İsgücü Özgürlüğü }\end{array}$ & $0-100$ & $\begin{array}{c}54,5 \\
55,5 \\
10,0 \\
0 \\
54,5 \\
\end{array}$ & $\begin{array}{l}- \\
- \\
- \\
- \\
- \\
\end{array}$ \\
\hline & $\begin{array}{l}\text { Fraser Enstitüsü/ } \\
\text { Dünya Ekonomik Özgürlük } \\
\text { End. } \\
\end{array}$ & $\begin{array}{l}\text { Kamu Sektörünün } \\
\text { Hacmi }\end{array}$ & $0-10$ & 5,3 & $127 / 169$ \\
\hline & $\begin{array}{l}\text { Dünya Ekonomik Forumu/ } \\
\text { Küresel Rekabet Gücü } \\
\text { Endeksi } \\
\end{array}$ & $\begin{array}{l}\text { Küresel Rekabet } \\
\text { Gücü }\end{array}$ & $1-7$ & 4,12 & $76 / 139$ \\
\hline & \begin{tabular}{|l} 
Dünya Bankası \& Uluslararas1 \\
Finans Kurumu/ \\
İs Yapma Endeksi
\end{tabular} & İş Yapma Kolaylığ & $0-100$ & 57,44 & $118 / 189$ \\
\hline & Dünya Bankasi/ & $\begin{array}{l}\text { Düzenlemelerin } \\
\text { Kalitesi }\end{array}$ & \multirow[t]{2}{*}{$-2,5 /+2,5$} & $-1,23$ & - \\
\hline & Dünya Yönetişim Göstergeleri & Yönetimin Etkinliği & & $-0,20$ & - \\
\hline
\end{tabular}

Kaynak: Ekonomist (2016), Economist Intelligence Unit's Democracy Index 2016 - Revenge of the "deplorables"; Freedom House (2016), Freedom in the World 2016; Freedom House (2016), Freedom of the Press 2016; Dünya Bankas1 (2017), World Governance Indicators 1996-2016, http:// info.worldbank.org/gov ernance/wgi/\#home, çevrimiçi veritabanı (Erişim: 22.07.2017); Uluslararası Şeffaflık Örgütü (2016), Corruption Perceptions Index 2016; Uluslararası Mülkiyet Hakları Birliği (2016), International Property Rights Index 2016; Heritage Vakfi (2017), 2017 Index of Economic Freedom; Fraser Enstitüsü (2016). Economic Freedom of the World 2016 Annual Report; Dünya Ekonomik Forumu (2016), The Global Competitiveness Report 2016-2017; Dünya Bankası ve Uluslararası Finans Kurumu (2016), Doing Business 2016 - Measuring Regulatory Quality and Efficiency. 
İran'da doğrudan yabancı sermaye yatırımlarının bir diğer önemli belirleyici unsurunu, ülkenin iç yatırım hukuku ve uluslararası anlaşmalar karş1sındaki durumu oluşturmaktadır. İran' da iç yatırım hukukunun ana gövdesini 2002 yılında yürürlüğe giren ve dış yatırımcıların daha fazla sektöre yönelebilmesine imkân tanımanın yanında, devlet uygulamaları nedeniyle ortaya çıabilecek şirket zararlarının karşılanmasından, kamulaştırma işlemleri neticesinde ilgili işletmeye tazminat ödenmesi garantisine, ana sermaye ya da ticari karların yurtdışına transferinden, olağanüstü durumlarda iflas eden yatırımcıların yatırım maliyetinin karşılanmasına, yabancı yatırımcıların ülkeye giriş işlemlerinden, ihtilafların çözümüne kadar yatırım ikliminin iyileştirilmesine dair birçok düzenlemeyi yürürlüğe koyan $\mathrm{Ya}$ bancı Yatırımı Teşvik ve Koruma Kanunu (Foreign Investment Promotion and Protection Act - FIPPA) oluşturmaktadır. ${ }^{44}$

1975 yılında kurulan ve fakat FIPPA'nın yatırım ortamını iyileştirmeye matuf düzenlemeleri ile birlikte 2002 yılı sonrasında güçlenerek kendi alanına odaklanma firsatı bulan Iran Yatırım, Ekonomik ve Teknik Yardım Kurumu (Organization for Investment, Economic and Technical Assistance of Iran - OIETAI); endüstriyel üretime ve ticarete dönük serbest yatırım bölgelerini, FIPPA kapsamında yabancı yatırımcıları destekleyici hükümet politikalarını ve piyasa düzenlemelerini, doğal kaynak ve işgücü zengini olması, geniş iç pazarı, geniş sektörel yelpazesi gibi ekonomik avantajlarını, bazı sektörlere ait vergi ertelemelerini ve stratejik coğrafi konumunu, yatırımcılara rekabet gücü avantajı sağlayan faktörler olarak deklare etmektedir. $^{45}$

$\mathrm{Bu}$ çerçevede FIPPA sonrasında ve OIETAI'nin kuvvetlendirilmiş yapısıyla birlikte İran'da yatırım ikliminin iyileştirilmesine yönelik ne tür reformlar yapıldığını gösteren Tablo 4 'ten, şirket kuruluş ve isimlendirme süreçlerinin kolaylaştıııldı̆̆ 1 , özellikle gelişmekte olan ve az gelişmiş ülkelerde yerleşik/verimsiz bürokratik yapı nedeniyle oldukça uzun süre alan ve yüksek işlem maliyetine neden olabilen yapı ruhsatı alma ve yap1 tamamlama prosedürleri ile elektrik ve suya erişim süreçlerine hız kazandırıldığı, ithalat ve ihracat işlemlerinin çabuklaştırıldığı ve dış ticaret prosedürlerinin basitleştirildiği, kredi finansmanı sağlamak noktasında sorun

44 İlgili metnin Türkçe versiyonuna ulaşmak için bkz. (http://www.investiniran.ir/en/ filepool/41/Foreign Investment-Promotion-and-Protection-Act-Turkish-?redirectpage $=\% 2$ fen $\% 2$ febook).

45 Organization for Investment, Economic and Technical Assistance of Iran, Why Iran, http://www.investinir an.ir/en/whyiran1, (03.11.2017). 
teşkil eden kredi notu ve/veya geçmiş finansal kimliğe dair bilgiye erişimin kapasitesi arttırıldığı, vergi yapısı daha sistematik ve işlevsel bir yapıya kavuşturulduğu, dış yatırımcılar için kritik bir önem taşıyan ve yatırım ve bağlantılı tüm faaliyetlerinin esaslı unsurunu oluşturan sözleşme hukukuna dair iyileştirici düzenlemelere gidildiği, ikili ya da çok taraflı hukuki ihtilaflar yaşayan ve yabancı bir ülkede bu tür sorunlarla baş edebilme kapasitesi nispeten sınırlı olan özellikle küçük yatırımcıların korunmasına dair önlemlerin kuvvetlendirildiği görülmektedir. Diğer taraftan, İran'ın 2013 yılında uygulamaya koyduğu yatırımcılardan ceza izni alma zorunluluğu getirerek girişim başlatma sürecini zorlaştırıcı bir uygulamayı yürürlüğe koyması ise son dönemde yatırım iklimini kötüleştiren tek olumsuz etken olarak kayda geçmiştir.

Tablo 4: İran'da Yatırım İklimini İyileştirmeye Yönelik Reformlar (2008-2017)

\begin{tabular}{|c|c|c|}
\hline Gösterge & Yil & Reform \\
\hline \multirow[t]{3}{*}{ Girişim Başlatma } & 2015 & $\begin{array}{l}\text { Şirket unvanı satın alınması ve kayıt prosedürleri kolaylaştırılmak } \\
\text { suretiyle iş yapma süreçleri hızlandırılmıştır. }\end{array}$ \\
\hline & 2011 & $\begin{array}{l}\text { Şirket unvanı aranması ve rezerve edilebilmesine imkân tanıyan bir } \\
\text { çevrimiçi portal hizmete alınarak iş yapma prosedürleri hafifletilmiştir. }\end{array}$ \\
\hline & 2010 & $\begin{array}{l}\text { Şirket kurulmasına dair prosedürlerin çevrimiçi bir portal üzerinden } \\
\text { gerçekleştirilebilmesine yönelik bir sistem hizmete alınarak Girişim } \\
\text { Başlatma süreçleri etkinlestirilmiștir. }\end{array}$ \\
\hline $\begin{array}{l}\text { Yapı Ruhsatı } \\
\text { İşlemleri }\end{array}$ & 2010 & $\begin{array}{l}\text { Tahran'da açtı̆̆ ofis marifetiyle yapı Ruhsatı işlemlerinin merkezi } \\
\text { bir sistem üzerinde daha hızlı gerçekleştirilmesine imkân tanınmış; } \\
\text { böylece yer onayları alma, izin belgesi oluşturma ve bitirme } \\
\text { sertifikalarını oluşturma süreci kolaylaştırılmış; ayrıca su ve elektrik } \\
\text { bağlantılarını elde etmek için gereken sure de azaltılmıștır. }\end{array}$ \\
\hline Elektriğe Erişim & 2015 & $\begin{array}{l}\text { Elektrik bağlatmak için gereken kazı izin ve harçlarını kaldırmak } \\
\text { kaydıyla elektriğe erişim prosedürleri kolaylaştırılmış ve } \\
\text { etkinleştirilmiştir. }\end{array}$ \\
\hline $\begin{array}{l}\text { Ticari Faaliyetin } \\
\text { Kolaylaştırılmas1 }\end{array}$ & 2017 & $\begin{array}{l}\text { Dış ticaret işlemlerinin tek elden sunulduğu ulusal-bazlı sistemin } \\
\text { altyapısı geliştirilerek ve genişletilerek ihracat ve ithalatı işlemleri } \\
\text { kolaylasstırıldı. }\end{array}$ \\
\hline Krediye Erişim & 2011 & $\begin{array}{l}\text { Özel bir kredi bürosu kurulmak suretiyle kredi bilgilerine erişim } \\
\text { kolaylaştırılmıștır. }\end{array}$ \\
\hline $\begin{array}{l}\text { Vergi Yükü ve Ödeme } \\
\text { Prosedürleri }\end{array}$ & 2010 & $\begin{array}{l}\text { Satış vergisinden, katma değer vergisi sistemine geçilerek vergi } \\
\text { ödeme prosedürü kolaylaștırılmıștır. }\end{array}$ \\
\hline $\begin{array}{l}\text { Sözleşmelerin } \\
\text { Uygulanabilirliği }\end{array}$ & 2011 & $\begin{array}{l}\text { Bazı belgelerin elektronik olarak dosyalanması, kısa mesaj yoluyla } \\
\text { bildirimi ve elektronik bir vaka yönetimi sistemi oluşturularak } \\
\text { sözlesmelerin uygulanabilirliği daha kolay ve daha hızlı hale getirildi. }\end{array}$ \\
\hline $\begin{array}{l}\text { Küçük Yatırımcıların } \\
\text { Korunması }\end{array}$ & 2013 & $\begin{array}{l}\text { Ekonomik faaliyetlerde taraflar arası şeffaflığın arttırılmasını } \\
\text { sağlayacak düzenlemeler yaparak küçük yatırımcıların korunmasına } \\
\text { yönelik önemler kuvvetlendirilmiştir. }\end{array}$ \\
\hline
\end{tabular}

Kaynak: Dünya Bankası (2017), Doing Business - Measuring Business Regulations, http://www. doingbusine ss.org/Reforms/Overview/Economy/iran, (Erişim: 22.10.2017). 
Diğer taraftan 2017 yılı itibarıyla toplam 57 ülkeyle iki taraflı yatırım anlaşması, İslam İşbirliği Teşkilatı ve Ekonomik İşbirliği Teşkilatı üyesi ülkeler ise bölgesel ve çok taraflı yatırım anlaşmaları akdedilmiş; yine, 46 ülkeyle de çift-yönlü vergi ertelemesi anlaşması imzalanmıştır. ${ }^{46}$ Doğrudan yabancı sermaye yatırımlarının teşviki amacıyla kurulan 7 adet serbest ticaret bölgesinde 20 yll vergi muafiyeti, ana sermaye ve karın transfer edilebilme olanakları, yabancı sermaye yatırımları için korunma ve garanti, vize ve oturum izinlerinin kaldırılması, çalışma ilişkileri sosyal güvenlik konularında kolaylaştırılmış mevzuat, parça mamullerin gümrük vergisinden muaf olarak ana karaya aktarılması gibi ilave imkânları sağlanmaktadır. ${ }^{47}$ Yine ülkenin daha iç bölgelerinde oluşturulan 14 adet özel ekonomik bölgede de sıfıra yakın işlem maliyeti ve formalite ile mal ihracatına yönelik kapsamlı avantajlar sağlanmaktadır. ${ }^{48}$

Nihayet Dünya Ekonomik Forumu tarafindan her yıl düzenli olarak yayımlanan Küresel Rekabet Gücü Endeksi kapsamında yapılan tespitlere göre, özellikle yerli paranın konvertibilite kısıtlarından kaynaklanan (döviz/dış para cinsinden) finansman sorunları yatırımcılar açısından en problemli ve riskli alan olarak tanımlanmaktadır. Bununla birlikte, ideoloji-baskın devlet yapılanması ve mezhep odaklı-yayılmacı dış politika anlayışı nedeniyle ortaya çıkardığı öngörülebilir olmayan/belirsiz siyasi ortam da yatırımc1ları tedirgin eden başlıca faktörlerden birisi olarak öne çıkmaktadır. İran ekonomisinin yapısal problemlerinin başında gelen enflasyon sorunu, bir taraftan yatırımların verimliliğine yönelik olumsuz etkisi nedeniyle doğrudan, hem de ülkenin makroekonomik istikrarını bozucu etkisi ile dolay11 olarak dış yatırımcı kararlarını olumsuz etkilemektedir. Özellikle reel yatırım yapmaları dolayısıyla doğrudan yabancı sermaye yatırımcılarının karar süreçlerine etki eden önemli bir etken de ulaşım, iletişim ve sair fiziki altyapının kalitesi olup, işbu alan da İran'ın en sorunlu alanlarından birisini teşkil etmektedir. Yine, iş süreçlerini yavaşlatma ve işlem maliyetlerini yükseltme potansiyeli barındıran verimsiz kamu bürokrasisi, kırtasiyecilik

46 OIETAI (2017), Iran Bilateral Investment Treaties, http://www.investiniran.ir/en/ ratified, (03.11.2017).

47 OIETAI (2017), Trade - Industrial Free Zones, http://www.investiniran.ir/en/ whyiran1/investmentncentive s/industialzones, (03.11.2017).

48 OIETAI (2017), Special Economic Zones, http://www.investiniran.ir/en/whyiran1/ investmentincentives/spe cialeconomiczones, (03.11.2017). 
ve yolsuzluk etmenleri yatırımcıların motivasyonunu kıran önemli diğer kritik parametreler olarak görülmektedir.

Tablo 5: İran'da Karşılaştırmalı ‘En Sorunlu Alanlar’ (2010-2016)

\begin{tabular}{lccc} 
Gösterge & $\mathbf{2 0 1 0}$ & Trend & $\mathbf{2 0 1 6}$ \\
\hline Finansmana Erişim & 18,3 & $\downarrow$ & 14,8 \\
\hline Politik İstikrarsılık & 14,4 & $\downarrow$ & 10,9 \\
\hline Enflasyon & 12,1 & $\uparrow$ & 12,2 \\
\hline Verimsiz Kamu Bürokrasisi & 11,3 & $\uparrow$ & 12,1 \\
\hline Yetersiz Altyapı & 11,1 & $\downarrow$ & 9,2 \\
\hline Dişlayııı İşgücü Piyasası & 7,1 & $\downarrow$ & 4,8 \\
Mevzuatı & 4,6 & $\downarrow$ & 4,0 \\
\hline Nitelikli İşgücü Eksikliği & 4,5 & $\downarrow$ & 3,6 \\
\hline Yerel İşgücünün Düşük İş Etiğgi & 4,4 & $\uparrow$ & 10,0 \\
\hline Yolsuzluk & 3,9 & $\uparrow$ & 5,4 \\
\hline Yabanc1 Para Düzenlemeleri & 3,1 & $\downarrow$ & 3,0 \\
\hline Vergi Düzenlemeleri & 2,3 & $\uparrow$ & 4,6 \\
\hline Vergi Oranları/Yükü & - & $\uparrow$ & 3,3 \\
\hline Yetersiz İnovasyon Kapasitesi & &
\end{tabular}

Kaynak: Dünya Ekonomik Forumu (2016), The Global Competitiveness Report 20162017.

Öte yandan, işgücü piyasasının esnekliğini kırmaya yönelik dışlayıcı düzenlemeler, aktif nüfusun iş etiği düzeyinin düşük olması, istikrarlı ve etkin bir vergi yapısının bulunmaması, yatırımcılar üzerindeki vergi yükünün görece yüksek olması, düşük inovasyon kapasitesi gibi unsurlar da, risk düzeyleri değişmekle birlikte İran'a yönelen DYSY önündeki belirleyici engeller olarak ya da iyileştirmeye ihtiyaç duyan alanlar olarak durmaktadir.

Hülasa, sivil ve siyasal özgürlükler dışında İran'a yönelen doğrudan yabancı sermaye akımları üzerinde ekonomik kurumların da genel olarak negatif etkide bulunduğu görülmektedir. Hâlihazır durumu itibarıyla zayıf bir kurumsal yapıya sahip olduğu aşikâr olan İran'ın, çok uluslu şirketlerin doğrudan yabancı sermaye yatırımı kararlarını kendisine yönlendirebilecek reform çabalarına rağmen avantajl1/rekabetçi bir yatırım iklimi 
oluşturabilmek hususunda kısır bir görünüm arz ettiğini söylemek yanlış olmayacaktır.

\section{Sonuç: 'İran İstisnacılı̆̆ı' mı?}

Doğrudan yabancı sermaye yatırımlar, küreselleşme süreci ile birlikte özellikle gelişmekte olan ülkelerde kalkınmanın finansmanı açısından en güvenilir dış kaynak halini almıştır. Bu çalışmada, doğrudan yabancı sermaye akımlarından potansiyeline nispetle oldukça düşük bir pay almakta olan İran'da ekonomik müşevvikler ve kurumsal kısıtların cari durumunun tespit edilmesi hedeflenmiştir. Yapılan incelemeler neticesinde İran'ın, cazip iç pazar büyüklüğü, tüketim eğilimi yüksek genç nüfusu, potansiyel ihraç pazarlarına yakınlığı nedeniyle pazar arayan çok uluslu işletmeler açısından uygun bir durak olduğu görülmüştür. İran'da, oldukça zengin olan enerji kaynaklarının kamu mülkiyetinde bulunması sebebiyle kaynak arayan çok uluslu işletmeler nazarında, fiyat istikrarsılıkları, kambiyo engelleri ve finansal sistemin zayıflığı dolayısıyla da etkinlik arayan çok uluslu işletmeler gözünde teşvik edici bir özellik taşımadığg anlaşılmıştır.

Diğer taraftan İran'ın, kurucu ideolojisinden beslenen ve güvenlik bürokrasisi aktörleri marifetiyle devamlılığını muhafaza edebilen siyasal sistemindeki kökleşmiş katılımcılık ve çoğulculuk problemleri ile iletişim, basın, örgütlenme gibi temel hak ve özgürlüklere ilişkin kısıtlar nedeniyle ÇUİ'ler açısından yeterli güven ortamının bulunmadığı tespit edilmiştir. Her ne kadar doğrudan yabancı sermaye yatırımların teşvik edecek şekilde, iş ortamını iyileştirmeye ve yatırımcıları korumaya matuf bir yasal düzenlemeye gidilmişse de, politik sistemin bürokrasi üzerindeki yozlaştırıcı etkisinin sebep olduğu yüksek yolsuzluk düzeyi ile yetersiz mülkiyet hakları güvencesi, etkili koruma mekanizmalarının yokluğu gibi sebepler dolayısıyla, çok uluslu işletmeler nezdinde avantajlı ortamının oluşturula-madığı değerlendirilmektedir.

Bütün bu negatif faktörlerin yanında, bir de İran'ın gerek bölgesel düzeyde izlediği mezhepsel-yayılmacı politikanın bir çıktısı olarak içine girmek du-rumunda kaldığı gerilimli rekabet ortamı, gerekse küresel düzlemde eko-nomik reaksiyonlara ve hatta uzun yıllardır süregelen ambargolara neden olabilen nükleer araştırma faaliyetlerinin ülke ekonomisi üzerinde ortaya çıkardığı sistemik riskler, yatırım güvenliği açısından çok uluslu işletmele-rin yatırım kararlarını olumsuz yönde motive ettiği bilinmektedir. 
Şimdiye kadar yapılan açıklamalar ışığında, ekonomik ve toplumsal büyük kaynakları ve potansiyeline rağmen, kurucu siyasal ideolojisinin sert bariyerleri ve esnekliği bulunmayan bu kısıtların konjonktürel olarak ülkeyi sürüklediği bölgesel ve/veya küresel ölçekli savrulmalar nedeni ile siyasal ideoloji-ekonomik gelişme arasında tercih ikilemine/çıkmazına sürüklenen İran'ın pozisyonunu, İran Ístisnacılı̆̆ $ı$ olarak adlandırmak, belki de yerinde olacaktır.

$\mathrm{Bu}$ kapsamda, İran istisnacılığının temel nedeni olan kurucu ideolojinin esnek olmayan yapısını dönüştürmenin zorluğu karşısında, en azından doğrudan yabancı sermaye yatırımlarını teşvik etmek hususunda ümitsizliğe kapılmak doğru olmayacaktır. Şöyle ki çok uluslu işletmelerin yatırım kararları üzerinde, ev sahibi ülkenin siyasal sistemi bakımından belirleyici olan etken, rejimin katılımcılık ya da çoğulculuk özelliğinden ziyade sürdürülebilir ve/veya öngörülebilir olmasıdır. Zira yatırımcılar, yatırım kararlarını verirken en azından orta vadeyi görebilmeyi umut ederler.

İşte bu doğrultuda, İran'da cari siyasal sistemin mevcut halini veri kabul ederek, ülkenin genel sosyo-ekonomik atmosferini belirleyen temel hak ve özgürlüklerin sınırlarının kademeli olarak da olsa genişletilmesi, hava kirliliği, yoğun trafik ve sair problemlere çözüm üretilerek yaşam kalitesinin yükseltilmesi, çoğunluğu kamu mülkiyetinde bulunan büyük işletmelerin özelleştirilmesi için etkili bir özelleştirme programı uygulanması, bağlantılı olarak bürokratik etkinliği arttıracak ve yolsuzluk algısını düşürecek risk yönetimi, kontrol ve denetim mekanizmalarının geliştirilmesi suretiyle toplumsal tansiyonun düşürülmesi, rant-odaklı ekonomik yapının kırılmasına ve ekonomide çeşitliliğin sağlanmasına yardımcı olarak çok uluslu işletmelerin yatırım kararlarını olumlu etkileyeceği cihetle tavsiye edilmektedir. İran'ın varoluşsal yanlarından birisi olan bölgesel ve küresel düzlemdeki dış politika hamlelerinden vazgeçmesini beklemek hayalperestlik olacağından, dış ilişkilerdeki gerilimi azaltmak maksadıyla da en azından agresif hamlelerden kaçınılması, ikili ve çok yönlü diplomatik ilişkilerini geliştirmesi suretiyle daha itidalli bir noktaya kaymasının da, güven ortamını ve yatırım iklimini olumlu yönde destekleyeceği dolayısıyla, faydalı olacağı mülahaza edilmektedir. 


\section{Kaynakça}

Acemoğlu, D. ve J. A. Robinson (2013). Ulusların Düşüşü - Güç, Zenginlik ve Yoksulluğun Kökenleri, 1. Baskı, Çev: F. R. Velioğlu. İstanbul: Doğan Kitap.

Agosin, M. R. ve R. Machado (2005). "Foreign Investment in Developing Countries: Does it Crowd in Domestic Investment?", Oxford Development Studies, Cilt: 33, Say1: 2, s.149-62.

Ahmed K. ve Diğerleri (2016). "Dynamics between Economic Growth, Labor, Capital and Natural Resource Abundance in Iran: An Application of the Combined Cointegration Approach", Resources Policy, Say1: 49, ss.213-21.

Alkin, E. (2001). "Büyüme İstikrar Yabancı Sermaye İlişkisi”, Ekonomik Istikrar, Büyüme ve Yabancı Sermaye, Ankara: TCMB, s.13-5.

Arı, T. (1999). 2000'li Yıllarda Basra Körfezinde Güç Dengesi, 4. Bask1, İstanbul: Alfa Basım.

Aslan, H. K. (2016). Iran'in Orta Asya Politikası (1991-2016), İRAM Analiz.

Aslan, M. (2016). Iran'da Enflasyon Sorunu, İRAM Analiz, No: 1.

Azzimonti, M. ve P. G. Sarte (2007). "Barriers to Foreign Direct Investment under Political Instability”, Economic Quarterly, Cilt: 93, Sayı: 3, s.287-315.

Baykal, M. (2014). Hukuksal ve Kurumsal Bağlamda Amerika Birleşik Devletleri ve Türkiye'de Doğrudan Yabancı Yatırımlar, İstanbul: On İki Levha Yayıncilik.

Berber, S (2013). “İran'ın Ekonomi Politikası, Yaptırımların Etkisi ve İkilemler", Bilge Strateji, Cilt: 5, Say1: 9, ss.61-84.

Brunetti, A. (1997). "Political Variables in Cross - Contry Growth Analysis", Journal of Economic Surveys, Cilt: 11, Say1: 2, s.163-90.

Bulutoğlu, K. (1970). 100 Soruda Türkiye'de Yabancı Sermaye, İstanbul: Gerçek Yayınevi.

Cohen, S. D. (2007). Multinational Corporations and Foreign Direct Investment: Avoiding, Simplicity, Embracing Complexity, New York: Oxford University Press. 
Comperative Constitution Project (2017). Iran's Constitution of 1979 with Amendments through 1989, Oxford University ve Hein Online, http:// www.constituteproject.org, (23.11.2017).

Cömert, F. (1998). "Yabanc1 Sermayenin Dünü, Bugünü ve Geleceği”, Hazine Dergisi, Say1: 12, s.1-25.

Çetin, T. (2012). "Yeni Kurumsal İktisat", Sosyoloji Konferansları, No: 45, ss.43-73.

Çinko, L. (2009). "Doğrudan Yabancı Sermaye Hareketlerinin Makroekonomik Etkileri”. Marmara Üniversitesi İ.I.B.F. Dergisi, Cilt: 26, Say1: 1, s.117-31.

Dickie, P. M. ve X. Fan (2000). "The Contribution of Foreign Direct Investment to Growth and Stability", ASEAN Economic Bulletin, Cilt: 17, Say1: 3, s.312-23.

Dunning, J. H. (1992). Multinational Enterprises and the Global Economy, MA: Addison Wesley.

Dünya Bankas1 (2017). Doing Business - Measuring Business Regulations, http://www.doing business.org/Reforms/Overview/Economy/iran, (Erişim: 22.10.2017).

Dünya Bankas1 (2017). World Development Indicators 2017.

Dünya Bankası (2017). Privatization Database (1990-2008), http://data. worldbank.org/data-catalog/privatization-database, çevrimiçi veritabanı (Erişim: 22.10.2017).

Dünya Bankası (2017). World Development Indicators, http://databank. worldbank.org/data/re ports.aspx? source=World-Development-Indicators, çevrimiçi veritabanı (Erişim: 22.10.2017).

Dünya Bankas1 (2017). World Governance Indicators 1996-2016, http:// info.worldbank.org/g overnance/wgi/\#home, çevrimiçi veritabanı (Erişim: 22.10.2017).

Dünya Bankas1 ve Uluslararas1 Finans Kurumu (2016), Doing Business 2016 - Measuring Regulatory Quality and Efficiency.

Dünya Ticaret Örgütü (2017). Trade Profiles 2017.

Financial Tribune (2017). "Iran 2nd Biggest FDI Destination in MENA", https://financialtrib une.com.articles/domestic-economy/65339/iran-2ndbiggest-fdi-destination-in-mena, (Erişim: 13.10.2017). 
Fraser Enstitüsü (2016). Economic Freedom of the World 2016 Annual Report.

Freedom House (2016). Freedom in the World 2016.

Freedom House (2016). Freedom on the Net 2016.

Freedom House (2016). Freedom of the Press 2016.

Heritage Vakfi (2017). 2017 Index of Economic Freedom.

İnat, K. ve Diğerleri (2016). İran - Suudi Arabistan Rekabetinin Bölgesel Etkileri, SETA Analiz, Sayı: 148.

Karamelikli, K. ve N. Alizadeh (2017). "Iran İslami Bankacılık Sistemi Üzerine Bir Değerlendirme”, Bankacılık ve Sigortacılık Araştırmaları Dergisi, Cilt: 2, Say1: 11, ss.36-58.

Kasper, W. ve M. E. Streit (1998). Institutional Economics: Social Order and Public Policy, Cheltenham: Edward Elgar Publishing.

Katouzian, H. ve H. Şahidi (2011). "21. Yüzy1lda İran - Siyaset, Ekonomi ve Çatışma”, 21.Yüzyılda İran, Çev: P. Güven, Ankara: Sitare Yayınları, ss.25-39.

Kegley, C. W. ve S. L. Blanton (2015). Dünya Siyaset, - Yönelim ve Dönüşüm, Çev: H. A. Gessler, Sakarya: Sakarya Üniversitesi Kültür Yayınları.

Koç, M. ve S. Afacan (2016). Iran'da Değişimin Dinamikleri, İRAM Perspektif, No: 1.

Lim, E. (2001). "Determinants of, and the Relation between Foreign Direct Investment and Growth: A Summary of the Recent Literature", IMF Working Paper, No: 175.

Mahdavy, H. (1970). "The Patterns and Problems of Economic Development in Rentier States: The Case of Iran", Der: M. A. Cook (Ed.), Studies in the Economic History of the Middle East-From the Rise of Islam to the Present Day, Oxford: Oxford University Press, ss.428-67.

Moosa, I. A. (2002). Foreign Direct Investment Theory, Evidence and Practice, London: Palgrave.

Mucuk, M. (2011). Doğrudan Yabancı Sermaye Yatırımları - Teori ve Türkiye Uygulaması, Konya: Çizgi Kitabevi. 
North, D. C. (2002). Kurumlar, Kurumsal Değişim ve Ekonomik Performans, Çev: G. Ç. Güven, İstanbul: Sabancı Üniversitesi Yayınlan.

OECD (2002). Foreign Direct Investment for Development - Maximizing Benefits Minimizing Costs, Paris.

Organization for Investment, Economic and Technical Assistance of Iran (2017). Why Iran, http://www.investiniran.ir/en/whyiran1, (03.11.2017).

Pierce, C. (2008), Corporate Governance in the Middle East and North Africa, London: GMB Publishing.

Samuelson, P. A. (1973). İktisat, Çev: Demir Demirgil, Gözden Geçirilmiş İlaveli Yeni Bası, İstanbul: Menteş Kitabevi.

Saygılığlu, N. ve S. Ar1 (2002). Etkin Devlet - Kurumsal Bir Tasart ve Politika Önerisi, İstanbul: Sabancı Üniversitesi Yayınları.

Saygın, E. (2017). Ortadoğu'da Kalkınmanın Finansmant-Doğrudan Yabancı Sermaye Yatırımlarl ve Kurumlar, İstanbul: Pınar Yayınları.

Seyidoğlu, H. (2001a). Uluslararası Finans, 3. Bask1, İstanbul: Güzem Yayınları.

--- (2001b). Uluslararası İktisat-Teori, Politika ve Uygulama, 14. Bask1, İstanbul: Güzem Yayınları.

Uluslararası Mülkiyet Hakları Birliği (2016). International Property Rights Index 2016.

Veblen, T. B. (1994). The Theory of Leisure Class, Dover Thrift Editions, Canada: General Publishing Company.

Yanar, R. (2015). "İki Ateş Arasında İran Ekonomisi”, Ortadoğu Analiz, Cilt: 7, Say1: 67, ss.90-3.

Yeğin, A. (2013). Iran Siyasetini Anlama Kılavuzu, SETA Rapor, No: 23. 